Florida International University FIU Digital Commons

$11-10-2011$

\title{
The Effects of Simulated Peccary Extirpation on Leaf Litter Dynamics, Reptiles, and Amphibians in a Neotropical Forest
}

Kelsey Reider

Florida International University, reider.12@gmail.com

DOI: $10.25148 /$ etd.FI11120506

Follow this and additional works at: https://digitalcommons.fiu.edu/etd

\section{Recommended Citation}

Reider, Kelsey, "The Effects of Simulated Peccary Extirpation on Leaf Litter Dynamics, Reptiles, and Amphibians in a Neotropical Forest" (2011). FIU Electronic Theses and Dissertations. 483.

https://digitalcommons.fiu.edu/etd/483 


\title{
FLORIDA INTERNATIONAL UNIVERSITY
}

Miami, FL

THE EFFECTS OF SIMULATED PECCARY EXTIRPATION ON LEAF LITTER DYNAMICS, REPTILES, AND AMPHIBIANS IN A NEOTROPICAL FOREST

\author{
A thesis submitted in partial fulfillment of the \\ requirements for the degree of \\ MASTER OF SCIENCE \\ in \\ BIOLOGY \\ by \\ Kelsey Elizabeth Reider
}

2011 
To: Dean Kenneth Furton

College of Arts and Sciences

This thesis, written by Kelsey Elizabeth Reider, and entitled The Effects of Simulated Peccary Extirpation on Leaf Litter Dynamics, Reptiles, and Amphibians in a Neotropical Forest, having been approved in respect to style and intellectual content, is referred to you for judgment.

We have read this thesis and recommend that it be approved.

Steven F. Oberbauer

Deron Burkepile

Maureen A. Donnelly, Major Professor

Date of Defense: November 10, 2011

The thesis of Kelsey Elizabeth Reider is approved.

$\begin{array}{r}\text { Dean Kenneth Furton } \\ \text { College of Arts and Sciences } \\ \hline \begin{array}{r}\text { Dean Lakshmi N. Reddi } \\ \text { University Graduate School }\end{array}\end{array}$

Florida International University, 2011 


\section{ACKNOWLEDGMENTS}

I would like to thank Steven Whitfield for introducing me to La Selva and to Mo Donnelly. I owe many thanks to Mo Donnelly for supporting my research in every way possible. I am indebted to my field assistants, Saras Yerlig, Pamela Valle, Ryan Kindermann, Katie Heyer, and Benjamin Shapiro who gave up months of their lives to work on this project. Their valiant efforts washing leaves until 11 PM, collecting peccary poop and frogs in the rain, tediously grinding leaf litter for 10 hours a day, and good attitudes made this project possible and fun. Vladislav Nachev, Viviana Loaiza, Seiichi Murasaki, Diego Dierick, Paul Maier, Danielle Palow, Patricia Jones, Bonnie Waring, Justin Nowakowski, Steven Whitfield, Sarah Ottney, Kurt von Kleist III, Erin Kuprewicz, Lilly Eluvathingal, and Amanda Wendt volunteered for shorter time periods but were also invaluable in the field or for lending equipment to me. My committee, including Maureen Donnelly, Steven Oberbauer, Deron Burkepile, and my labmates including Justin Nowakowski, Vivian Maccachero, Monica Isola, Seiichi Murasaki, Lilly Eluvathingal, James Watling, Steven Whitfield, Rudolf von May, Robert Hegna, and Luke Linhoff provided advice, support, and comments on the manuscript and numerous proposals. Philip Stoddard and James Fourqurean also provided valuable advice on drafts

of the proposal. Pamela Parker and the FIU Seagrass Lab assisted with CNP chemistry of litter and soil. I would like to thank Walter Carson (University of Pittsburgh) for allowing me to use the peccary exclusion plots and La Selva Biological Station for maintaining the fences. Deedra McClearn, Orlando Vargas, Danilo Brenes, Bernal Matarrita, and Lubin Brenes were especially helpful at La Selva. Finally, thanks to everyone at La Selva who participated in an art or game night - you guys made living at 
La Selva super-mega tuanis. My research was supported by an Organization for Tropical Studies Research Fellowship through the Christiane and Christopher Tyson Fund, Idea Wild, a FIU Latin American and Caribbean Center Tinker Field Grant, the American Society of Ichthyologists and Herpetologists Gaige Award, the Chicago Herpetological Society, and Plants in Design. Soils were exported under Costa Rican MINAET permit DGVS-057-2011 to K. Reider, and imported under USDA APHIS permit P330-11-00052 to K. Jayachandran. Research was conducted under FIU IACUC permit 09-016 to M. Donnelly, and MINAET permit 145-2009-SINAC to K. Reider. 
ABSTRACT OF THE THESIS

THE EFFECTS OF SIMULATED PECCARY EXTIRPATION ON LEAF LITTER DYNAMICS, REPTILES, AND AMPHIBIANS IN A NEOTROPICAL FOREST

\author{
by
}

Kelsey Elizabeth Reider

Florida International University, 2011

Miami, Florida

Professor Maureen A. Donnelly, Major Professor

Peccaries are known to play a significant role in shaping the diversity of habitats and structure of plants in rain forests. However, very little is known about their roles in regulating animal populations. I review the ways peccaries increase disturbance, create habitat diversity, provide resources, act as predators, and might otherwise directly and indirectly affect other animals. To determine effects of simulated peccary extirpation on the detrital food web, I examined the hypotheses that a reduction of peccary density on fenced exclusion plots would cause changes in the amount and quality of leaf litter as habitat for leaf litter reptiles and amphibians. I found that compared to open controls, exclusions had significantly deeper litter and more rapid cellulose decomposition.

Exclusions were thus expected to provide more habitat and prey for litter amphibians and reptiles than control plots, but, paradoxically, encounters of reptiles and amphibians were greater on controls. 
I. INTRODUCTION ...............................................

II. CHAPTER 1: ECOSYSTEM ENGINEERING AND CASCADING INTERACTIONS OF RAIN FOREST PECCARIES

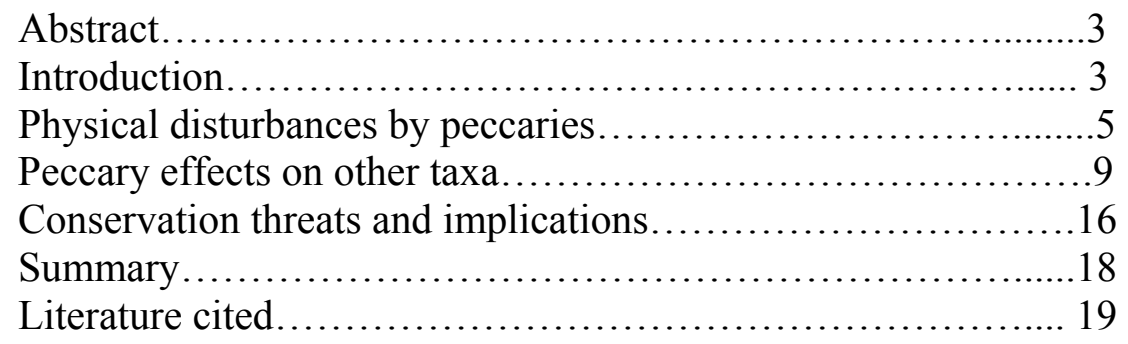

III. CHAPTER 2: THE EFFECTS OF SIMULATED PECCARY EXTIRPATION ON LEAF LITTER DYNAMICS, REPTILES, AND AMPHIBIANS IN A NEOTROPICAL FOREST

Abstract........................................................ 28

Introduction................................................. 29

Methods.................................................... 35

Results................................................43

Discussion............................................ 46

Summary .................................................. 55

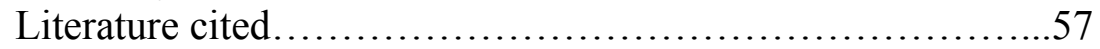

IV. CONCLUSIONS............................................. 70 


\section{INTRODUCTION}

I first became interested in the ecosystem engineering effects of peccaries on leaf litter organisms while working at Los Amigos Biological Station in southeastern Peru. Watching a large herd of white-lipped peccaries bulldoze their way through the leaf litter impressed me, and I could not help but think that the peccaries were creating substantial impacts, both direct and indirect, on the processes involved in litter decomposition and the populations of organisms linked to the detrital food web. I already thought, like many other researchers, that an apparent overpopulation of collared peccaries at La Selva Biological Station (Costa Rica), was contributing to an observed decline in leaf litter reptiles and amphibians, and my observations in Peru fed my interest in the topic of peccaries and my suspicions about them at La Selva. I realized that although the collared peccaries should have less of an impact on the leaf litter fauna than white-lipped peccaries (because they differ in body mass, herd size, and foraging intensity), it would be easy to test the hypothesis that peccaries are contributing to the La Selva amphibian and reptile declines because of the presence of five large mammal exclusion plots. If I detected more frogs and lizards inside the exclusions than outside, I would have fairly strong evidence that peccaries have some negative effects on litter organisms. However, I was also aware that there is another side to the story, because as seed predators, peccaries are very important in determining tropical forest diversity and structure, and there are expected to be many negative consequences of peccary extirpation. At the same time, peccary populations are threatened throughout the Neotropics because people like to eat them, because peccaries are often involved in conflicts with humans in fragmented 
forest-agricultural landscapes, and because of habitat loss. With that wider conservation perspective in mind, but with the original question of whether peccaries are contributing to the amphibian and reptile declines observed at La Selva lingering, I set out to learn about the effects of peccaries on the detrital food web and other animals in the leaf litter.

In the first chapter, I review the available literature on the ecosystem engineering effects of peccaries and their potential interactions with other animal populations. Chapter One fills a gap in the available reviews on peccaries because I synthesize information about their ecosystem level effects on other animals and annotate this information with my own observations from the field. In Chapter Two, I present the results of an experimental peccary extirpation from exclusion plots at La Selva Biological Station in Costa Rica. The conditions inside the exclusion plots mimic a forest in which peccaries have been hunted out, because white-lipped peccaries were actually extirpated from La Selva and the surrounding forest, and because the fences effectively exclude collared peccaries, but not other smaller terrestrial mammals like agoutis. Chapter Two is particularly important for tropical forest ecology because next to nothing is known about the direct or indirect effects of peccaries on other animal communities in tropical forests, yet understanding the complex interactions between peccaries and tropical forests is necessary to provide conservation strategies for both. 


\title{
CHAPTER 1: ECOSYSTEM ENGINEERING AND CASCADING INTERACTIONS OF RAIN FOREST PECCARIES
}

\begin{abstract}
Peccaries are a dominant component of Neotropical forest faunas and are known to play a significant role in shaping the diversity of habitats and structure of plants in rain forests. However, very little is known about their roles in driving animal community diversity or regulating animal populations. Here I review the ways peccaries create habitat diversity and disturbance, act as predators, and provide resources for plants and other animals. I also discuss the possibility that peccaries have strong direct and indirect effects on other animals. The two common species of peccaries are in very little danger of becoming extinct because of their geographically broad distributions, but peccary populations are extremely threatened because of human hunting pressures throughout the Neotropics, and their extirpation could result in significant changes in forest structure and biodiversity.
\end{abstract}

\section{INTRODUCTION TO PECCARIES}

Three species of peccaries (Tayassuidae; ungulates closely related to pigs and hippopotomi) occur in the Neotropics. Of these three, two species (collared peccaries, Pecari tajacu Linnaeus, and white-lipped peccaries, Tayassu pecari Link) have a wide geographic distribution and are considered important ecosystem engineers in the tropical lowland forests of Central and South America (Beck 2005). Ecosystem engineers are species that modify the biotic or abiotic environment, maintaining or causing changes in the availability of resources for other species (Jones \& Guiterrez 2007, Jones et al. 1994, 
1997). Recent reviews have synthesized the roles of peccaries in shaping understory plant communities, seed dispersal, tree recruitment, and forest dynamics (Sowls 1997, Beck 2005, 2006). I will briefly summarize these important roles and then discuss the roles of peccaries as agents of physical disturbance, as ecosystem engineers, their direct and indirect effects on other animals, and how these factors relate to conservation concerns and implications for tropical forests.

Peccaries are an important component of the animal biomass in Neotropical forests. The two species have different effects on forest patches because they differ in individual and group size. Collared peccaries are smaller than white-lipped peccaries, weighing $25 \mathrm{~kg}$ on average (maximum weight: $30 \mathrm{~kg}$ from Sowls 1997). White-lipped peccaries weigh an average of $32 \mathrm{~kg}$ (Bodmer \& Ward 2006) but can weigh up to $50 \mathrm{~kg}$ (Beck 2005). White-lipped peccaries can account for the highest biomass among terrestrial mammals in intact forests $\left(370 \mathrm{~kg} / \mathrm{km}^{2}\right.$; citations in Beck 2006). Both species form large foraging groups (up to 50 individuals per group for collared peccaries and 400 individuals per group for white-lipped peccaries; Beck 2005). Peccaries form the largest foraging groups of all Neotropical mammals (Eisenberg \& Redford 2000), and their impact depends in part on herd size.

Peccary diets consist mainly of fruit (Bodmer 1989, Keuroghlian et al. 2004, Beck 2005, Bodmer \& Ward 2006), particularly palm fruits (Beck 2006). Peccaries consume fruits from a wide variety of palm species, destroying most seeds (up to $80 \%$ ) through mastication and digestion and dispersing the rest (Beck 2005, 2006). In this way, peccaries strongly affect the distribution and demography of palms, a major component of the lowland rain forest floras, and other tree species (Beck 2005, 2006). 


\section{ECOSYSTEM EFFECTS VIA PHYSICAL DISTURBANCE}

Peccaries create substantial physical disturbance through wallowing, geophagy (i.e., consuming soil), and foraging. These behaviors alter both the structure and chemistry of the forest floor. Alteration of the environment by peccaries creates new habitats, e.g., wallows and mineral licks, and influences the diversity and distribution of other species. In this way, peccaries function as ecosystem engineers (Jones et al. 1997, Beck 2005, Wright \& Jones 2006). The ecosystem effects of peccaries are felt over a large landscape. Collared peccaries have large home ranges (up to 685 ha; citations in Beck 2005), but often repeatedly visit certain areas within those ranges thus concentrating their foraging activities and physical disturbances. White-lipped peccaries have been shown to utilize very large home ranges of over 20,000 ha (Kiltie \& Terborgh 1983), so their intense foraging activities might be relatively dilute compared to collared peccaries.

PeCCARY WALlOWS.-Collared peccaries and white-lipped peccaries create and maintain wallows (Sowls 1997, Gascon and Zimmerman 1998, Beck 2008). Peccary wallows are patches of bare soil created by deliberate digging and rolling on the forest floor and are maintained by frequent visitation. Wallows create small depressions where water accumulates, leading to the creation of small ponds (Hobbs 2006). In the Amazon basin, peccary wallows are often located in the terra firme forest, which is never flooded by streams or rivers. The only other terrestrial lentic water bodies in terra firme forest are ponds, oxbow lakes, and small pools in depressions left by uprooted trees (Beck et al. 2010, pers. obs). Peccary wallows generally hold water longer than other natural ponds and depressions (Zimmerman \& Bierregaard 1986, Zimmerman \& Simberloff 1996, Beck 
et al. 2010). Peccaries thus create small, reliable wetlands in terra firme uplands. In addition to aquatic invertebrates, peccary wallows are extremely important breeding habitat for many species of amphibians (Zimmerman \& Bierregaard 1986, Gascon 1991, 1995, Zimmerman \& Simberloff 1996, Beck et al. 2010). The presence of peccary wallows thus affects the diversity of anurans and other aquatic organisms (e.g., odonates, mosquitoes) that require standing water. In addition, because peccary wallows create non-randomly (located within the group home range) but unevenly distributed habitat within forests, peccaries may also affect the distributions of organisms that rely on wallows. Zimmerman \& Bierregaard (1986) went so far as to recommend that the minimum critical size of preserves for forest amphibians should be determined on the basis of the size of reserve required to sustain white-lipped peccary populations.

MINERAL LICKS.-White-lipped peccaries may also act as engineers in Amazonian forests by creating and maintaining mineral licks. Mineral licks are sites where animals aggregate to consume soil. Because ingested soils usually have a higher mineral and/or clay content compared to surrounding non-eaten soils (Emmons \& Stark 1979), frugivores such as tapirs, peccaries, parrots, macaws, etc. may consume soil to compensate for mineral deficiencies associated with frugivory (Kreulen 1985; Tracy \& Mcnaughton 1995; Holdo et al. 2002). Alternatively, the clay in soil eaten by frugivores could reduce acidosis (Kreulen 1985), detoxify secondary plant compounds (Oates 1978, Diamond et al. 1999, Gilardi et al. 1999), and/or reduce intestinal parasite loads (Mahaney et al. 1996). 
Large herd size and intense digging activity of white-lipped peccaries promote the maintenance and expansion of salt licks (pers. obs.). Licks range in size from a few meters to hundreds of meters in diameter (Klaus et al. 1998). In the Amazon they are deep, muddy pits with large trees but lack dense understory vegetation and often containing standing water and animal feces. The licks themselves seem to provide poor habitat for aquatic invertebrates and amphibians, possibly because of poor water quality, but may support significant bacterial and algal growth (pers. obs.). Deeply-cut access paths are spread across the surrounding forest, where the high concentration of visiting ungulates (especially tapirs, white-lipped peccaries, collared peccaries, and deer) results in substantial trampling of the leaf litter and seedlings in the area around licks (pers. obs.).

Mineral licks are centers of mammal diversity within tropical forests. Frugivorous ungulates (including tapirs, white-lipped peccaries, and red brocket deer) and frugivorous bats are the most common visitors (Montenegro 2004, Bravo et al. 2008, Tobler 2008). These animals will travel for many kilometers outside their home ranges to visit licks (Montenegro 2004, Tobler 2008). Boas may also concentrate around licks to eat bats that visit the licks (pers. obs.).

Very little is known about the creation of licks in forests, but peccaries may play an important role in their creation as well as maintenance when wallows expose mineralrich soils (pers. obs.). The degree to which peccaries contribute to lick formation and maintenance is unknown, but seems likely to be significant on the basis of the large numbers of peccaries in herds and the extent of their disturbance during each visit (pers. obs.). If their role is substantial, they have a significant effect upon the diversity and 
distribution of other lick-dependent species and on species who are excluded from licks and surrounding areas because of the unfavorable conditions found there.

FORAGING.-Peccaries also create new habitats by promoting the establishment of some plants by creating litter gaps through rooting while foraging. Rooting (and wallowing) displaces the leaf litter covering soil, and undoubtedly alters the chemical properties of soil on the forest floor by changing the environmental conditions. These litter gaps allow small-seeded, litter-gap dependent species to germinate (Metcalfe 1996, Metcalfe \& Turner 1998). The creation of litter gaps by peccaries is concentrated under palms, where peccaries forage most heavily (Beck 2007). In addition, although peccaries destroy most of the seeds they eat, some are expectorated or defecated far from the parent tree which increases chances for survivorship (Beck 2005). The combined effects of seedling and seed destruction and the removal of leaf litter may promote the establishment of other species and therefore increased plant diversity, especially around palms (Beck 2006).

Rooting and wallowing activities of white-lipped peccaries are more intense than collared peccaries largely because of differences in herd size, body size, and foraging intensity, but both white-lipped and collared peccaries also consume leaves, tubers, roots, and rhizomes. These intensive foraging activities likely have a negative effect on plant survivorship for trampled individuals. Expectoration and trampling of seeds, on the other hand, might positively affect seed survival (Beck 2006). In addition to consuming seeds, peccaries create ecosystem-level effects by trampling seedlings, thus negatively influencing plant recruitment, spatial distribution, and population dynamics (Clark \& Clark 1989, Fragoso 1997, Wright et al. 2000, Roldán \& Simonetti 2001, Silman et al. 2003, Beck 2007). 
By controlling the above-ground plant structure of tropical forests, peccaries also influence physical properties such as light penetration, temperature, humidity, and soil moisture. These changes affect litter and soil chemistry, and leaf litter decomposition, which will be considered in detail below.

\section{EFFECTS OF PECCARIES ON OTHER TAXA}

Disturbances by peccaries clearly promote species diversity of both plants and animals by engineering variation in available habitats. Other ungulates have important effects on community composition, diversity, and abundance of plants and animals from many taxonomic groups in different habitats (Singer et al. 1984, McNaughton et al. 1988, Friend \& Cellier 1990, Hobbs 1996, Suominen et al. 1999, Cote et al. 2004, Wardle \& Bardgett 2004, Allombert et al. 2005b, Danell et al. 2006, Pringle et al. 2007, Vavra et al. 2007, Fornara \& Du Toit 2008, Greenwald et al. 2008). The competitive interactions between peccary species, and with other frugivorous species, have recently been reviewed by Beck (2005). However, next to nothing is known about the direct or indirect effects of ungulates on other animal communities in tropical forests. I will discuss the mechanisms (as predators, as resource providers, and indirect effects; for competition see Beck 2005) by which changes in abundance or density of peccaries may drive changes in animal community composition or abundance using examples from wild ungulates in natural habitats. The conservation implications of these effects will also be described in the next section. 
PECCARIES AS PREDATORS.-The extent to which predation by peccaries creates topdown effects on animal populations is unknown, but animal parts (including insects, frogs, and snakes) make up $12 \%$ of white-lipped peccary diets and up to $20 \%$ of collared peccary diets, enough for some authors to consider peccaries omnivores rather than frugivores (Kiltie 1981; Bodmer 1989, 1991a, 1991b; Fragoso 1999). Predation by ungulates has been important in cases of true omnivory as in the wild pig (Sus scrofa; Jolley et al. 2010), among species that are more herbivorous than peccaries when the available diet does not satisfy their nutritional needs (as in red deer, Cervus elaphus, on islands; Furness 1988), and by incidental omnivory while feeding on plants (Polis et al. 1989). For peccaries, the degree of 'frugivory-herbivory-omnivory' varies according to regional vegetation types, local frugivore guild compositions, and can vary dramatically in seasonal forests (Desbiez 2007, Keuroghlian \& Eaton 2008). Peccary diets are known to include invertebrates, eggs, frogs, fish, snakes, and small mammals (refer to citations and tables in Beck 2005, Keuroghlian \& Eaton 2008).

Since peccaries have extremely effective digestion mechanisms (including a sacculated fore-stomach for microbial fermentation and a strong mastication apparatus for cracking hard seeds; Bodmer 1991b, Bodmer \& Ward 2006), animal remains are likely underrepresented in diet studies derived from fecal and stomach content analysis. Small, leaf litter-dwelling amphibians and reptiles, for example, are extremely common in tropical forests (Guyer \& Donnelly 2005) and could make up a substantial portion of peccary diet as a result of incidental consumption while foraging. Opportunistic and incidental consumption (and trampling) the eggs of frogs, lizards, turtles, and snakes in the leaf litter might be an even more important effect of peccaries on the leaf litter species 
through effects on early life-history stages thereby reducing the overall success of reproductive activities by adults. Soft-bodied animals are unlikely to be detected in diet studies because they are either masticated completely or digested very quickly and completely. Identification of prey DNA from peccary scats may overcome some of the limitations of hard parts and stable isotope analyses (Waits \& Paetkau 2005, Zhang et al. 2006, Casper et al. 2007).

The case of peccaries switching to a more omnivorous diet to compensate for low fruit quantity or quality might have significant effects on the leaf litter fauna in places where the peccary populations are too large to be supported by the available fruit falls, as would occur in small forest fragments. In addition, Beck (2005 and citations within) has suggested that because peccaries prefer fruits with insect larvae, they may exert top-down control on insect populations and indirectly affect seed recruitment.

PeCCARIES AS ResourCes.-Because of their large size and abundance in tropical forests, peccaries can function to provide critical resources for other organisms. For example jaguars, Panthera onca, and pumas, Puma concolor, are important in maintaining diversity and structure of tropical forests (Terborgh et al. 2001, 2008). These large cats rely heavily on peccaries as a prey source, and peccaries make up a significant and often dominant portion of jaguar and puma diets (Núñez et al. 2000, Garla et al. 2001, Gonzalez \& Miller 2002, Moreno et al. 2006, Weckel et al. 2006a, 2006b). In addition to serving as a food source for big cats, peccaries are also important resources for human populations in tropical forests, which is discussed in the next section. 
Peccary carcasses, urine, and feces are likely to be important food resources for the microbial, fungal, and arthropod communities of tropical forests. Addition of peccary feces and urine can affect primary productivity by providing nutrient pulses to the microbial and fungal decomposers (Suominen \& Danell 2006, Gruner et al. 2008). Feeley \& Terborgh (2005) found that mammal defecation may have positive effects on growth rates and aboveground plant productivity by increasing microbial activity and the rate of litter decomposition (Pastor \& Naiman 1992, Wardle \& Bardgett 2004). Nutrient addition can alter leaf litter quality and forest structure (Hobbs 1996, Gilliam 2006), because tree reproduction in tropical forests appears to be limited by nitrogen and leaf litter decomposition rates seem to be phosphorus limited (Kaspari et al. 2008).

Peccary defecation occurs in specific locations in the forest called latrines, and is thus a clumped resource in tropical forests. Nutrient enrichment by latrines of other Neotropical mammals, howler monkeys, has been studied in Venezuela. Feeley (2005) found that soil and leaf litter $\mathrm{N}$ and $\mathrm{P}$ concentrations and availability both were enriched near latrines, probably leading to the corresponding enhancement of fine root biomass under latrines. Peccary latrines probably concentrate limiting nutrients which act as important resources for plants and other animals. In addition, relatively long-distance movements between foraging sites (peccaries can travel over $10 \mathrm{~km}$ per day; Beck 2005), and long food retention time (up to 52 hours, Beck 2005) peccaries promote the transfer of nutrients throughout the forest as herds move.

INDIRECT EFFECTS ON OTHER FAUNA.-Peccaries have strong effects on the physical properties of habitats. Examples include peccary effects on forest structure and leaf litter 
disturbance, which in turn affect understory light penetration, temperature, wind, humidity, soil moisture, mineral content, nutrient cycling, and hydrology. Through such indirect effects, peccaries should have strong cascading interactions with other fauna because many species utilize microhabitats within specific bounds of physical properties, like humidity. Most amphibians, for example, are very sensitive to changes in temperature and humidity because they are poikilothermic and have permeable skin. Most studies of ungulates in Neotropical forests have focused on cascades caused by predator or competitive release, while few have focused on the direct and indirect effects of ungulates on other elements of the tropical forest fauna.

Ungulates have strong cascading effects on syntopic animal communities in temperate forests. Deer provide a good comparison because the cascading effects of deer in temperate ecosystems have been studied relatively thoroughly because deer have major effects on economics, agriculture, transportation, and disease transmission (reviewed by Côte et al. 2004). DeCalesta (1994) investigated the cascading effects of deer density in a Pennsylvania forest and found that species richness and abundance of intermediate canopy nesting songbirds declined at high deer density. The indirect effects of deer can also change the interactions between seed availability, small mammals, birds, and insects (Ostfeld et al. 1996, McShea 2000).

The effects of deer vary from site to site because sites with different soils and plant communities respond differently to deer browsing, making it difficult to draw strong inferences about the relationship between deer browsing and animal diversity. For every study reporting that deer increase diversity and abundance of other species, a different study obtains an opposite result. The fact that temperate and boreal terrestrial 
ungulates can either promote or inhibit litter and soil animals depending on complex local conditions underscores the need for experimental evidence from tropical forests. Suominen (1999) and Suominen et al. (1999) found a lower abundance and higher diversity of ground-dwelling insects at browsed sites in Sweden. However, Suominen et al. (2003) reported trends of higher abundance, species richness, and diversity of ground dwelling beetles in grazed nutrient-rich sites, but diversity was significantly lower in grazed 'nutrient-poor sites in Finland. Wardle et al. (2001) found that deer grazing resulted in lower abundances of arthropods in a temperate forest in New Zealand. Greenwald et al. (2008) quantified the indirect effects of deer foraging on leaf litter organisms in Ohio; they found that salamander, snake, gastropod abundance and invertebrate species richness were significantly higher in deer grazed plots compared to exclosure plots. Allombert et al. $(2005 \mathrm{a}, \mathrm{b})$ suggested that a possible mechanism for some of the indirect effects of deer was a change in leaf litter quality and a change in the understory vegetation structure. Peccaries in tropical forests differ from deer because peccaries generally have a diet which is much less focused on foliage. However, deer and peccaries are both expected to affect other organisms by altering properties of the leaf litter, soil, and understory.

Studies on wild pigs might also provide some insight into the possible effects of peccaries on leaf litter dynamics and other animals. Singer et al. (1984) found that wild pig (Sus scrofa) rooting accelerated decomposition and loss of nutrients on the forest floor. Leaf litter mass and depth in lightly-rooted sites were not statistically different from unrooted sites. However, leaf litter mass and depth were 59 - $65 \%$ lower in forests with intense rooting pressures compared to exclusion treatments, and leaf litter dependent 
mammals were virtually eliminated from the rooted forests. Wild pigs and peccaries have different foraging and rooting behaviors, and cascading effects of peccaries (along with all other tropical forest species) on other animals have been poorly studied. Studies from collared peccary exclusion plots at lowland rain forest sites in Costa Rica and Panama suggest peccaries may affect the abundance of understory herbaceous cover, quantity and quality of leaf litter, the abundance of leaf litter arthropods, and/or the diversity of understory birds (Royo \& Carson 2005, N. Michel, unpublished data.). The cascading effects of peccaries in tropical forests may be especially important where peccary population dynamics have been significantly altered.

Studies of African ungulates provide a valuable example of how important the role of ungulates can be in ecosystem-level dynamics. Although the African savanna and its large mammalian fauna differs from the Neotropical rainforest in several key parameters, notably the large individual and group sizes of African ungulates compared to the relatively small-bodied and less abundant Neotropical ungulates and the ecosystem type, research has revealed that African systems cannot be fully understood without a detailed understanding of the large mammals, and vice versa (McNaughton et al. 1988). For example, ungulates have been shown to have strong, cascading affects from the ground to the canopy on arthropods (mediated through ungulate-induced changes in vegetation cover), lizards (mediated by ungulate-induced changes in tree cover and arthropod prey, and long-lived trees; Pringle et al. 2007). Fornara \& Du Toit (2008) found evidence that ungulate dung and urine deposition on the African savanna led to more rapid decomposition and nitrogen mineralization, offsetting the effects of poor litter quality caused by ungulates at heavily browsed sites. Just as in Africa, understanding of 
Neotropical forests should be deeply connected to the consideration of large, abundant mammals and we cannot begin to understand the processes driving ecosystem processes and Neotropical forest diversity without also understanding the roles of large mammals like peccaries and the potential consequences of their elimination.

\section{CONSERVATION THREATS AND IMPLICATIONS}

Both rainforest peccary species are currently listed by the Convention for International Trade in Endangered Species in Appendix II (Reyna-Hurtado et al. 2008), and the Chacoan peccary (Catagonus wagneri) is currently listed as endangered in CITES Appendix I (Altricher et al. 2008). Unsustainable levels of hunting, habitat destruction, and forest fragmentation are serious threats to the persistence of large mammals in tropical forests. Although collared and white-lipped peccaries are probably not threatened with extinction at the species level because of their broad distributions, each and every population is threatened with extirpation because of overhunting and habitat loss (Beck et al. 2008).

Humans have direct and indirect effects on peccary populations. Peccaries are very desirable as bush meat because of their high fat content and large herds which increase hunting success (Sowls 1997). Extirpations from overhunting are common, especially in tropical forest fragments and in areas of the Amazon with large influxes of settlers into tropical forests because of widespread use of firearms and the market introduction of peccary products, including high-end peccary skin gloves in Europe (Bodmer et al. 1997, Sowls 1997, Beck et al. 2008). Overhunting of peccaries and other frugivores can reduce seed dispersal distances and abundance and promote clumped 
seedling distributions and reduced diversity of seedlings (Guariguata et al. 2000, Wright et al. 2000, Roldan \& Simonetti 2001, Wright et al. 2007, Peres \& Palacios 2007, Stoner et al. 2007, Beckman \& Muller-Landau 2007, Dirzo et al. 2007). In addition, widespread and unsustainable harvesting of palms can reduce the carrying capacity for frugivores, directly reducing peccary populations (Bodmer \& Ward 2006).

The persistence of peccaries in fragmented forests depends heavily upon the availability of fruits throughout the year. Where forests exhibit strong seasonality, large tracts of forests are necessary to sustain peccary populations because large areas have higher tree species richness, and thus greater availability of fruits year-round (Fragoso 1998, Carrillo et al. 2002, Keuroghlian \& Eaton 2008). White-lipped peccaries rely more heavily on fruits than collared peccaries (Beck 2005) and thus require a greater variety of habitats and larger areas to find sufficient food (Keuroghlian \& Eaton 2008). Because of these foraging needs, area requirements, and large group size, white-lipped peccaries are more susceptible to local extinction than collared peccaries (Peres 1996, Sowls 1997). In fact, white-lipped peccaries have been almost completely extirpated from Central American forests, and Beck (2006) recommends that they be listed in CITES Appendix I. The extirpation of both or either peccary species may drastically alter the cascading positive and negative effects peccaries have on the structure of tropical forests and biodiversity.

Just as extirpation of peccaries can cause drastic changes in tropical forests, an overpopulation of peccaries as a result of predator and competitive release could be detrimental. Some study sites in the Neotropics (e.g., La Selva in Costa Rica, Cocha Cashu in Perú) have effectively created protection from poaching, yet jaguars have likely 
been extirpated at Cocha Cashu (Beck 2005). Peccaries and other herbivore populations might increase dramatically after predator release, leading to 'ecological meltdown' in response to high herbivore density (Terborgh et al. 2008). At La Selva and Barro Colorado Island in Panama, like many forests in Central America, collared peccaries also experience competitive release because white-lipped peccaries have been extirpated. Collared peccary populations might then increase to the limits dictated by their food resources, i.e., fruits and frogs. Whether by extirpation or overpopulation, human-induced changes in peccary populations threaten the diversity and structure of Neotropical forests.

\section{SUMMARY}

White-lipped and collared peccaries are important ecosystem engineers in tropical forests. Peccary modification of the physical and biotic environment likely creates strong cascading peccary-animal interactions which influence the structure and diversity of tropical forests. The degree to which peccaries contribute to regulation of diversity and abundance of animals is unknown because of complex interactions and limited research effort. The knowledge gap regarding these important ecosystem engineers may represent one of the greatest unknowns in tropical forest ecology. Understanding the roles peccaries play in tropical ecosystems and the factors that contribute to their persistence may be vital for maintaining the structure of tropical forests, as well as for supporting human populations in the tropics. Research efforts should be directed towards understanding the complex interactions between peccaries and tropical forests to provide conservation strategies for both. 


\section{LITERATURE CITED}

AlLOMBert, S., A. J. GASTON, AND J. L. MARTin. 2005a. A natural experiment on the impact of overabundant deer on songbird populations. Biol Conserv. 126: 1-13.

Allombert, S., S. StOckTON, AND J. L. MARTin. 2005b. A natural experiment on the impact of overabundant deer on forest invertebrates. Conserv Biol. 19: 19171929.

Altrichter, M., A. TABer, A. Noss. And L. MAFFeI. 2008. Catagonus wagneri. In: IUCN 2011. IUCN Red List of Threatened Species. Version 2011.1. $<$ www.iucnredlist.org>. Downloaded on 16 September 2011.

BECK H. 2005. Seed predation and dispersal by peccaries throughout the Neotropics and its consequences: a review and synthesis. In P. M. Forget, J. E. Lambert, P. E. Hulme, and S. B. Vander Wall (eds.). Seed Fate: Predation, Dispersal, and Seedling Establishment, pp. 77-115. University Press, Cambridge, UK.

BECK, H. 2006. A review of peccary-palm interactions and their ecological ramifications across the Neotropics. J Mammal. 87: 519-530.

BECK, H. 2007. Synergistic impacts of ungulates and falling palm fronds on saplings in the Amazon. J Trop Ecol. 23: 599-602.

BECK, H. 2008. Tropical ecology. In S. E. Jorgensen and B. Fath (eds.). Encyclopedia of ecology, pp. 3636-3624. Elsevier, Oxford, UK.

Beck, H., A. Taber, M. Altrichter, A. Keuroghlian, and R. Reyna. 2008. Pecari tajacu. In IUCN 2011: IUCN Red List of Threatened Species. Version 2011.1. $<$ www.iucnredlist.org $>$. Downloaded on 03 August 2011.

Beck, H., P. ThebPanya, AND M. Filiaggi. 2010. Do Neotropical peccary species (Tayassuidae) function as ecosystem engineers for anurans? J Trop Ecol. 26: 407414.

Beckman, N. G., AND H. C. Muller-Landau. 2007. Differential effects of hunting on pre-dispersal seed predation and primary and secondary seed removal of two Neotropical tree species. Biotropica. 39: 328-339.

BODMER, R. E. 1989. Ungulate biomass in relation to feeding strategy within Amazonian forests. Oecologia. 81: 547-550.

BoDMER, R. E. 1991a. Strategies of seed dispersal and seed predation in Amazonian ungulates. Biotropica. 23: 255-261. 
BODMER, R. E. 1991b. Influence of digestive morphology on resource partitioning in Amazonian ungulates. Oecologia. 85: 361-365.

Bodmer, R. E., J. F. EISENBERG, AND K. H. REDFORD. 1997. Hunting and the likelihood of extinction of Amazonian mammals. Conserv Biol. 11: 460-466.

BODMER R., AND D. WARD. 2006. Frugivory in large mammalian herbivores. In K. Danell, R. Bergstroem, P. Duncan, and J. Pastor (eds.). Large Herbivore Ecology Ecosystem Dynamics and Conservation, pp. 232-260. University Press, Cambridge, UK.

Bravo, A., K. E. Harms, R. D. Stevens, And L. H. EMmons. 2008. Collpas: Activity hotspots for frugivorous bats (Phyllostomidae) in the Peruvian Amazon. Biotropica. 40: 203-210.

CARrillo, E., J. C. SAEnZ, AND T. K. Fuller. 2002. Movements and activities of whitelipped peccaries in Corcovado National Park, Costa Rica. Biol Conserv. 108: 317 324.

Casper, R. M., S. N. Jarrnan, B. E. Deagle, N. J. Gales, and M. A. Hindell. 2007. Detecting prey from DNA in predator scats: A comparison with morphological analysis, using Arctocephalus seals fed a known diet. J Exp Mar Biol Ecol. 347: 144-154.

Clark, D. B., AND D. A. CLARK. 1989. The role of physical damage in the seedling mortality regime of a Neotropical rain-forest. Oikos. 55: 225-230.

Côte, S. D., T. P. Rooney, J. P. Tremblay, C. Dussault, and D. M. Waller. 2004. Ecological impacts of deer overabundance. Annual Review of Ecology Evolution and Systematics. 35: 113-147.

Danell K., R. Bergstroem, P. Duncan, And J. Pastor (eds.). 2006. Large Herbivore Ecology Ecosystem Dynamics and Conservation. University Press, Cambridge, UK. 506 pages.

DeCAlESTA, D. S. 1994. Effect of white-tailed deer on songbirds within managed forests in Pennsylvania. J Wildl Manage. 58: 711-718.

DesBIEZ, A. 2007. Wildlife conservation in the Pantanal: habitat alteration, invasive species and bushmeat hunting. PhD Dissertation, University of Kent, UK.

DiAmond, J., K. D. Bishop, AND J. D. GiLARDi. 1999. Geophagy in New Guinea birds. Ibis. 141: 181-193. 
Dirzo, R., E. MENDOZA, AND P. ORTíZ. 2007. Size-related differential seed predation in a heavily defaunated Neotropical rain forest. Biotropica. 39: 355-362.

EISENBERG, J. F., AND K. H. REDFORD. 2000. Mammals of the Neotropics: Ecuador, Bolivia, Brazil. University of Chicago Press, Chicago, U.S.A.

EMMONS, L. H., AND N. M. STARK. 1979. Elemental composition of a natural mineral lick in Amazonia. Biotropica. 11: 311-313.

FEELEY, K. 2005. The role of clumped defecation in the spatial distribution of soil nutrients and the availability of nutrients for plant uptake. J Trop Ecol. 21: 99102.

FEELEY, K., AND J. TERBORGH. 2005. The effects of herbivore density on soil nutrients and tree growth in tropical forest fragments. Ecology. 86: 116-124.

FORNARA, D. A., AND J. T. Du TOIT. 2008. Browsing-induced effects on leaf litter quality and decomposition in a southern African savanna. Ecosystems. 11:238249.

Fragoso, J. M. V. 1997. Tapir-generated seed shadows: Scale-dependent patchiness in the Amazon rain forest. J Ecol. 85: 519-529.

Fragoso, J. M. V. 1998. Home range and movement patterns of white-lipped peccary (Tayassu pecari) herds in the northern Brazilian Amazon. Biotropica. 30: 458469.

Fragoso, J. M. V. 1999. Perception of scale and resource partitioning by peccaries: behavioral causes and ecological implications. J Mammal. 80: 993-1003.

Friend, G. R., AND K. M. CELliER. 1990. Wetland Herpetofauna of Kakadu National Park, Australia: seasonal richness trends, habitat preferences and the effects of feral ungulates. J Trop Ecol. 6: 131-152.

FURNESS, R. W. 1988. Predation on ground-nesting seabirds by island populations of red deer Cervus elaphus and sheep Ovis. J Zool. 216: 565-573.

GARLA, R. C., E. Z. F. SETZ, AND N. GoBBI. 2001. Jaguar (Panthera onca) food habits in Atlantic rain forest of southeastern Brazil. Biotropica. 33: 691-696.

GASCON, C. 1991. Population-level and community-level analyses of species occurrences of central Amazonian rain-forest tadpoles. Ecology. 72: 1731-1746.

GASCON, C. 1995. Tropical larval anuran fitness in the absence of direct effects of predation and competition. Ecology. 76: 2222-2229. 
GASCON, C., AND B. Zimmerman. 1998. Of frogs \& ponds \& peccaries. Natural History. 107: 43-45.

Gilardi, J. D., S. S. Duffey, C. A. MunN, AND L. A. Tell. 1999. Biochemical functions of geophagy in parrots: Detoxification of dietary toxins and cytoprotective effects. J Chem Ecol. 25: 897-922.

GILLIAM, F. S. 2006. Response of the herbaceous layer of forest ecosystems to excess nitrogen deposition. J Ecol. 94: 1176-1191.

GonZÁlez, C. A. L., AND B. J. Miller. 2002. Do jaguars (Panthera onca) depend on large prey? West N Am Nat. 62: 218-222.

GREenwald, K. R., L. J. Petit, AND T. A. WAite. 2008. Indirect effects of a keystone herbivore elevate local animal diversity. J Wildl Manage. 72: 1318-1321.

Gruner, D. S., J. E. Smith, E. W. Seabloom, S. A. Sandin, J. T. Ngai, H. Hillebrand, W. S. Harpole, J. J. ElSER, E. E. Cleland, M. E. S. Bracken, E. T. Borer, AND B. M. BOLKER. 2008. A cross-system synthesis of consumer and nutrient resource control on producer biomass. Ecol Lett. 11: 740-755.

Guariguata, M. R., J. J. R. AdAme, AND B. Finegan. 2000. Seed removal and fate in two selectively logged lowland forests with constrasting protection levels. Conserv Biol. 14: 1046-1054.

GuYer, C., AND M. A. Donnelly. 2005. Amphibians and Reptiles of La Selva, Costa Rica, and the Caribbean Slope. University of California Press, California, U.S.A.

HobBS, N. T. 1996. Modification of ecosystems by ungulates. J Wildl Manage. 60: 695713.

HoBBS, N. T. 2006. Large herbivores as sources of disturbance in ecosystems. In K. Danell, R. Bergstroem, P. Duncan, and J. Pastor (eds.). Large Herbivore Ecology Ecosystem Dynamics and Conservation, pp. 261-288. University Press, Cambridge, UK.

Holdo, R. M., J. P. DudLeY, AND L. R. MCDowell. 2002. Geophagy in the African elephant in relation to availability of dietary sodium. J Mammal. 83: 652-664.

Jolley, D. B., S. S. Ditchkoff, B. D. Sparklin, L. B. Hanson, M. S. Mitchell, And J. B. GRAND. 2010. Estimate of herpetofauna depredation by a population of wild pigs. J Mammal. 91: 519-524.

JONES, C. G., AND J. L. GUTIÉRREZ. 2007. On the purpose, meaning, and usage of the physical ecosystem engineering concept. In Cuddington, K., J. E. Byers, W. G. 
Wilson, and A. Hastings (eds.). Ecosystem engineers: plants to protists, pp. 3-24 . Academic Press, Burlington, U.S.A.

JONES, C., J. LAWTON, AND M. SHACHAK. 1994. Organisms as ecosystem engineers. Oikos. 69: 373-386.

Jones, C. G., J. H. LAWTON, AND M. SHACHAK. 1997. Positive and negative effects of organisms as physical ecosystem engineers. Ecology. 78: 1946-1957.

Kaspari, M., M. N. García, K. E. Harms, M. SAntana, S. J. Wright, And J. B. YavitT. 2008. Multiple nutrients limit litterfall and decomposition in a tropical forest. Ecol Lett. 11: 35-43.

Keuroghlian, A., AND D. P. EATON. 2008. Fruit availability and peccary frugivory in an isolated Atlantic forest fragment: Effects on peccary ranging behavior and habitat use. Biotropica. 40: 62-70.

Keuroghlian, A., D. P. Eaton, And W. S. Longland. 2004. Area use by white-lipped and collared peccaries (Tayassu pecari and Tayassu tajacu) in a tropical forest fragment. Biol Conserv. 120: 411-425.

KILtIE, R. A. 1981. Stomach contents of rain-forest peccaries (Tayassu pecari and Tayassu tajacu). Biotropica. 13: 234-236.

Kiltie, R. A., AND J. TeRBORGH. 1983. Observations on the behavior of rain-forest peccaries in Peru - why do white-lipped peccaries form herds. Zeitschrift Fur Tierpsychologie-Journal of Comparative Ethology. 62: 241-255.

Klaus, G., C. Klaus-Hugi, AND B. SchMid. 1998. Geophagy by large mammals at natural licks in the rain forest of the Dzanga National Park, Central African Republic. J Trop Ecol. 14: 829-839.

KREULEN, D. A. 1985. Lick use by large herbivores - a review of benefits and banes of soil consumption. Mamm Rev. 15: 107-123.

Mahaney, W. C., R. G. V. Hancock, S. Aufreiter, and M. A. Huffman. 1996. Geochemistry and clay mineralogy of termite mound soil and the role of geophagy in chimpanzees of the Mahale mountains, Tanzania. Primates. 37: 121134.

McNaughton, S. J., R. W. Ruess, And S. W. Seagle. 1988. Large mammals and process dynamics in African ecosystems. BioScience. 38: 794-800.

MCSHEA, W. J. 2000. The influence of acorn crops on annual variation in rodent and bird populations. Ecology. 81: 228-238. 
METCALFE, D. J. 1996. Germination of small-seeded tropical rain forest plants exposed to different spectral compositions. Canadian Journal of Botany-Revue Canadienne De Botanique. 74: 516-520.

Metcalfe, D. J., AND I. M. TuRner. 1998. Soil seed bank from lowland rain forest in Singapore: Canopy-gap and litter-gap demanders. J Trop Ecol. 14: 103-108.

Moreno, R. S., R. W. KAYS, AND R. SAMUdio JR. 2006. Competitive release in diets of ocelot (Leopardus pardalis) and puma (Puma concolor) after jaguar (Panthera onca) decline. J Mammal. 87: 808-816.

Montenegro, O. L. 2004. Natural licks as keystone resources for wildlife and people in Amazonia. PhD Dissertation, University of Florida, U.S.A.

NúÑEZ, R., B. MiLlER, AND F. LINDZEY. 2000. Food habits of jaguars and pumas in Jalisco, Mexico. J Zool. 252: 373-379.

OATES, J. F. 1978. Water, plant and soil consumption by Guereza monkeys (Colobus guereza) - relationship with minerals and toxins in the diet. Biotropica. 10: 241253.

OstFeld, R. S., C. G. Jones, AND J. O. WolfF. 1996. Of mice and mast. Bioscience. 46: 323-330.

PASTOR, J., AND R. NAIMAN. 1992. Selective foraging and ecosystem processes in boreal forests. Am Nat. 139: 690-705.

Peres, C. A. 1996. Population status of white-lipped Tayassu pecari and collared peccaries T. tajacu in hunted and unhunted Amazonian forests. Biol Conserv. 77: 115-123.

Peres, C. A., AND E. PALACIOS. 2007. Basin-wide effects of game harvest on vertebrate population densities in Amazonian forests: Implications for animal-mediated seed dispersal. Biotropica. 39: 304-315.

Polis, G. A., C. A. Myers, AND R. D. Holt. 1989. The ecology and evolution of intraguild predation - potential competitors that eat each other. Annu Rev Ecol Syst. 20: 297-330.

Pringle, R. M., T. P. Young, D. I. Rubenstein, And D. J. McCAuley. 2007. Herbivoreinitiated interaction cascades and their modulation by productivity in an African savanna. Proceedings of the National Academy of Sciences. 104: 193-197.

Reyna-Hurtado, R., A. Taber, M. Altrichter, J. Fragoso, A. Keuroghlian, and H. BECK. 2008. Catagonus wagneri. In: IUCN 2011. IUCN Red List of Threatened 
Species. Version 2011.1. <www.iucnredlist.org>. Downloaded on 16 September 2011.

ROLDÁN, A. I,. AND J. A. SimONETTI. 2001. Plant-mammal interactions in tropical Bolivian forests with different hunting pressures. Conserv Biol. 15: 617-623.

ROYO, A. A. AND W. P. CARSON. 2005. The herb community of a tropical forest in central Panama: Dynamics and impact of mammalian herbivores. Oecologia. 145: 66-75.

Silman, M. R., J. W. Terborgh, And R. A. Kiltie. 2003. Population regulation of a dominant-rain forest tree by a major seed-predator. Ecology. 84: 431-438.

Singer, F. J., W. T. SWANK, AND E. E. C. CleBSCH. 1984. Effects of wild pig rooting in a deciduous forest. J Wildl Manage. 48: 464-473.

SowLS, L. K. 1997. Javelinas and other peccaries: their biology, management, and use. Texas A\&M University Press, Texas, U.S.A.

Stoner, K. E., P. RibA-Hernandez, K. VulineC, AND J. E. LAMBert. 2007. The role of mammals in creating and modifying seedshadows in tropical forests and some possible consequences of their elimination. Biotropica. 39: 316-327.

SUOMINEN, O. 1999. Impact of cervid browsing and grazing on the terrestrial gastropod fauna in the boreal forests of Fennoscandia. Ecography. 22: 651-658.

SuOMINEN, O., AND K. DANELL. 2006. Effects of large herbivores on other fauna. In K. Danell, R. Bergstroem, P. Duncan, and J. Pastor (eds.). Large Herbivore Ecology Ecosystem Dynamics and Conservation, pp. 383-412. University Press, Cambridge, UK.

SuOMINEN, O., K. DANELL, AND J. P. BRYANT. 1999. Indirect effects of mammalian browsers on vegetation and ground-dwelling insects in an Alaskan floodplain. Ecoscience. 6: 505-510.

Suominen, O., J. Niemela, P. Martikainen, P. Niemela, AND I. Kojola. 2003. Impact of reindeer grazing on ground-dwelling Carabidae and Curculionidae assemblages in Lapland. Ecography. 26: 503-513.

Terborgh, J., L. Lopez, P. NuÑez, M. RaO, G. Shahabuddin, G. Orihuela, M. Riveros, R. Ascanio, G. H. Adler, T. D. LAMBert, AND L. BAlbas. 2001. Ecological meltdown in predator-free forest fragments. Science. 294: 1923-1926.

Terborgh, J., G. Nuñez-IturRi, N. C. A. Pitman, F. H. C. Valverde, P. Alvarez, V. SWAMY, E. G. PRINGLE, AND C. E. T. PAINE. 2008. Tree recruitment in an empty forest. Ecology. 89: 1757-1768. 
Tobler, M. W. 2008. The ecology of the lowland tapir in Madre de Dios, Peru: using new technologies to study large rainforest mammals. PhD Dissertation, Department of Wildlife and Fisheries Sciences, Texas A\&M University, U.S.A.

TRACY, B. F., AND S. J. MCNAUGHTON. 1995. Elemental analysis of mineral lick soils from the Serengeti National Park, the Konza Prairie and Yellowstone National Park. Ecography. 18: 91-94.

VAVRA, M., C. G. PARKS, AND M. J. Wisdom. 2007. Biodiversity, exotic plant species, and herbivory: The good, the bad, and the ungulate. Forest Ecol and Management. 246: 66-72.

WAits, L. P., AND D. PAetKAU. 2005. Noninvasive genetic sampling tools for wildlife biologists: A review of applications and recommendations for accurate data collection. J Wildl Manage. 69: 1419-1433.

WARDLE, D., AND R. BARDGETT. 2004. Human-induced changes in large herbivorous mammal density: The consequences for decomposers. Frontiers in Ecology and the Environment. 2: 145-153.

Wardle, D. A., G. M. BArker, G. W. Yeates, K. I. Bonner, And A. Ghani. 2001. Introduced browsing mammals in New Zealand natural forests: Aboveground and belowground consequences. Ecol Monogr. 71: 587-614.

Weckel, M., W. Giuliano, And S. Silver. 2006a. Jaguar (Panthera onca) feeding ecology: Distribution of predator and prey through time and space. J Zool. 270: 25-30.

WeCKel, M., W. GiUliano, AND S. SiLVER. 2006b. Cockscomb revisited: Jaguar diet in the Cockscomb Basin Wildlife Sanctuary, Belize. Biotropica. 38: 687-690.

Wright, J. P., AND C. G. JONES. 2006. The concept of organisms as ecosystem engineers ten years on: Progress, limitations, and challenges. Bioscience. 56: 203-209.

Wright, S. J., H. Zeballos, I. Domínguez, M. M. Gallardo, M. C. Moreno, and R. IBÁÑEZ. 2000. Poachers alter mammal abundance, seed dispersal, and seed predation in a Neotropical forest. Conserv Biol. 14: 227-239.

Wright, S. J., K. E. Stoner, N. Beckman, R. T. Corlett, R. Dirzo, H. C. MullerLandau, G. Nuñez-Iturri, C. A. Peres, And B. C. WANG. 2007. The plight of large animals in tropical forests and the consequences for plant regeneration. Biotropica. 39: 289-291.

ZHANG, B., M. LI, L. MA, AND F. WEI. 2006. A widely applicable protocol for DNA isolation from fecal samples. Biochem Genet. 44: 503-512. 
ZIMMERMAN, B. L., AND R. O. BIERREGAARD. 1986. Relevance of the equilibrium-theory of island biogeography and species area relations to conservation with a case from Amazonia. J Biogeogr. 13: 133-143.

ZIMMERMAN, B. L., AND D. SimBerlofF. 1996. An historical interpretation of habitat use by frogs in a central Amazonian forest. J Biogeogr. 23: 27-46. 


\title{
CHAPTER 2: THE EFFECTS OF SIMULATED PECCARY EXTIRPATION ON LEAF LITTER DYNAMICS, REPTILES, AND AMPHIBIANS IN A NEOTROPICAL FOREST
}

\begin{abstract}
The loss or reduction of Neotropical mammal densities, especially the frugivore and seed predator guilds, can have detrimental cascading effects on forest diversity and structure. Peccary extirpation may serve as a model for mammal defaunation because collared (Pecari tajacu) and white-lipped (Tayassu pecari) peccaries are large, often numerically dominant mammals that contribute substantially to the mammalian biomass in Neotropical forests, have wide-reaching effects because of extensive distributions and large home ranges, and their extirpation is a likely throughout the Neotropics as human population increases affect remaining tropical forests. In my study, I used peccary exclusion in five $20 \mathrm{~m} \times 50 \mathrm{~m}$ plots to simulate peccary extirpation, a condition found in tropical forests throughout Central and South America as a result of overhunting and fragmentation, to understand the consequences of peccary loss on ecosystem level processes like leaf litter dynamics and cellulose decomposition. I also examined if peccary effects on leaf litter have any effects on an important group of leaf-litter dwelling organisms, the litter amphibians and reptiles. I found that peccary exclusion did result in a significantly reduced abundance of peccaries inside plots, and that the reduction in peccary abundance coincided with significantly deeper litter and more rapid cellulose decomposition rates inside exclusion plots compared to non-fenced controls. Exclusion plots were thus thought to provide more habitat and potential prey for litter amphibians
\end{abstract}


and reptiles than control plots, but paradoxically, the densities of reptiles and amphibians encountered on control plots were higher than on exclusions. These results suggest that peccaries do not have overwhelmingly negative effects on litter amphibians and reptiles and should not be considered major factors in the ongoing amphibian and reptile population declines at La Selva.

\section{INTRODUCTION}

The world's tropical forests are under immense pressure from human activities, resulting in enormous loss of plant and animal species (Bradshaw et al. 2009). Considerable ecological research has concentrated on the effects of biodiversity loss on ecosystem structure and functioning (Hooper et al. 2005, Hector et al. 2007, Thebault \& Loreau 2006, Isbell et al. 2011, Wardle et al. 2011). Neotropical rain forest mammals affect forest diversity and structure, yet forest fragmentation, habitat degradation, diseases introduced from livestock, and overhunting threaten forest mammal populations (Bodmer et al. 1997, Peres 2001, Grelle 2005). The loss or reduction of Neotropical mammal densities, especially from frugivore and seed predator guilds, has detrimental effects on forest diversity and structure (Terborgh 1988, Dirzo \& Miranda 1990, Wright \& Duber 2001, Wright et al. 2000, Silman et al. 2003, Peres \& Palacios 2007, Wright et al. 2007a, 2007b, Stoner et al. 2007, Terborgh et al. 2008, Estes et al. 2011). Mammalian frugivores promote plant diversity by dispersing seeds, or limit diversity by reducing the abundance of preferred plant species by seed predation. Frugivores also negatively affect plants by trampling and uprooting them while foraging (Gill 2006, Hester et al. 2006, Ward 2006). Medium-to-large sized frugivorous mammals are often among the first 
casualties of land-use change and overhunting in Neotropical forests. Large, extinctionprone frugivorous mammals contribute to the maintenance of plant and animal diversity, community composition, and forest structure, so their elimination poses a serious threat to biodiversity and hurdle to conservation (Terborgh et al. 2001, Bodmer \& Ward 2006, Terborgh et al. 2008). Defaunated forests undergo major shifts in plant species compositions that, over time, could lead to major changes in forest structure and ecosystem function.

The effects of extirpation or extinction of large mammals on other animals in Neotropical forests is relatively unknown because of complex positive and negative interactions and limited empirical research. Peccary extirpation may serve as a model for mammal population declines because collared (Pecari tajacu) and white-lipped (Tayassu pecari) peccaries are large, often numerically dominant mammals, contribute substantially to the mammalian biomass in Neotropical forests, and have wide-reaching effects because of extensive distributions and large home ranges (Beck 2005, 2006). In addition, peccaries are often among the first large mammals to disappear as a result of land-use change and overhunting; white-lipped peccaries have already been extirpated from most of Central America (Beck 2005). Collared peccaries often fare relatively well in fragmented and degraded landscapes, but resulting increases in contact with humans and conflicts over peccary damage to agricultural products put collared peccaries at high risk for being over-hunted (Gongora et al. 2011). Given the rapid rates of deforestation and the potential for over-hunting by humans, the extirpation of collared and white-lipped peccaries is a strong possibility throughout the Neotropics (Beck 2005, Beck et al. 2008, Gongora et al. 2011, Reyna-Hurtado et al. 2008). 
Peccaries are a dominant component of intact Neotropical forest faunas, and are known to play a significant role in shaping the diversity and structure of microhabitats, plant, and animal communities in rain forests. Peccaries are considered ecosystem engineers because of important trophic and non-tropic interactions with other species. For example, white-lipped peccaries in the Amazon create wallows which hold water long into the dry season (Beck et al. 2010). For amphibians, these wallows create novel aquatic habitats that support reproductive activities. Peccaries also create novel habitats in the form of litter gaps, mineral licks, and latrines (Clark \& Clark 1989, Beck 2005, 2007, Beck et al. 2010). In addition, peccaries determine and maintain Neotropical forest structure through seed predation, seed expectoration, and seedling trampling (Silman et al. 2003, Roldán \& Simonetti 2001, Clark \& Clark 1989, Fragoso 1997, Wright et al. 2000, Fragoso et al. 2003, Paine \& Beck 2007). Finally, peccaries cause substantial physical disturbance on the forest floor through wallowing, geophagy, foraging, and trampling.

In forests where peccary densities have been reduced (through intense hunting, habitat fragmentation, or experimental exclusion), seed and seedling removal and recruitment is disproportionately lower than in forests with higher mammal densities (Guariguata et al. 2000, Wright et al. 2000, Roldán \& Simonetti 2001, and Keuroghlian $\&$ Eaton 2009). As a result, the extirpation of peccaries from Neotropical forests is expected to have wide-reaching negative effects on plant diversity and forest structure. Because peccaries have a myriad of direct and indirect, positive and negative effects on plants and other animals (reviewed in Beck 2005), peccary extirpation should strongly affect the distribution and demography of animal communities. By controlling the 
above-ground plant structure of tropical forests, peccaries also influence physical properties such as light penetration, temperature, humidity, and soil moisture, which in turn likely affect litter and soil chemistry, leaf litter decomposition, and the animals that live in the leaf litter.

Peccary extirpation could also affect ecosystem processes such as nutrient cycling and decomposition via loss of dung and urine inputs, and a reduction in litter turnover associated with peccary foraging activities. Peccaries defecate repeatedly in specific locations known as latrines (Sowls 1997), which are likely to increase nutrient availability and decomposition rates in the forest immediately around latrines. Nutrient pulses from large mammals in the form of dung and urine are regularly deposited in tropical forests, and are likely important for the spatial distribution of soil nutrients and decomposition at a fine scale (Feeley 2005, Feeley \& Terborgh 2005), which is appropriate for many leaf-litter dwelling organisms. Peccaries generally travel through the forest in large foraging groups (Beck 2005), mixing the leaf litter as they root and dig in the litter and soil and probably affecting decomposition. To maintain high rates of biomass production, rapid litter decomposition provides nutrients for new plant growth. Experimental nutrient addition has previously increased decomposition rates in tropical forests (Hobbie \& Vitousek 2000, Kaspari et al. 2008). Tropical rain forest soils are notoriously nutrient poor (Vitousek 1984) and depend on rapid decomposition and cycling to fuel new growth. Thus, a loss of nutrient-rich dung and urine, and a loss of litter turnover following peccary extirpation could slow decomposition rates and remineralization of $\mathrm{C}, \mathrm{N}$, and $\mathrm{P}$, reducing nutrient availability for plants and microbial decomposers. Reduced nutrient availability could have downstream effects on primary 
productivity, fruit production, and other ecosystem processes from the forest floor to the canopy.

Leaf litter is decomposed by fungi and bacteria that form the basis for the detrital food web (Bardgett \& Wardle 2003, Wardle \& Bardgett 2004, Milton \& Kaspari 2007). Since most members of the diverse Neotropical leaf litter arthropod community feed directly upon microbial litter decomposers, a strong relationship exists between environmental nutrient concentrations and the invertebrate litter fauna (McGlynn 2006, McGlynn et al. 2007, 2009, Shik \& Kaspari 2010). The litter arthropods are in turn the major food source for many leaf litter vertebrates including amphibians and reptiles. The leaf-litter reptiles and amphibians probably are a vital link in the detrital food web. In Neotropical forests, leaf litter amphibians and reptiles are prominent among the top predators in the detrital food web, and consist of a highly diverse group of terrestrial anurans, lizards, and snakes that depend heavily on the leaf litter as a microhabitat and as sites for foraging and reproduction (Scott 1976, Lieberman 1986, Heinen 1992). Leaf litter anurans are often numerically dominant vertebrates in Neotropical forests, contribute substantially to the biomass of the detrital food web, and represent important trophic links among the detrital, aquatic, and arboreal food webs. Peccary extirpation could affect the amount of leaf litter habitat available for organisms, the amount of food available, and the microhabitat conditions required for survival of leaf litter organisms such as amphibians and reptiles.

In addition to being highly diverse, leaf litter amphibians and reptiles are very sensitive to changes in microhabitat quality (Scott 1976, Lieberman 1986, Heinen 1992, Whitfield et al. 2007, Whitfield 2011). Leaf litter amphibians and reptiles rely upon a 
thick layer of leaf litter to prevent body and egg desiccation. The leaf litter layer serves as an important buffer to daily thermal fluctuation, which is important because amphibians and reptiles are poikilotherms, Many Neotropical litter amphibians and reptiles appear may be living near their critical thermal maxima (Huey et al. 2009, Duarte et al. 2009). In addition to indirect effects of peccary extirpation, amphibian and reptile populations could also be directly affected by peccaries via consumption, trampling of adults, and perhaps more importantly, trampling or consumption of egg clutches in the leaf litter. Trampling by a herd of peccaries could reduce the reproductive success of litter reptiles and amphibians, which deposit egg clutches in the leaf litter. Whitfield et al. (2007) hypothesized that the long-term decline of litter reptiles and amphibians at La Selva Biological Station in Costa Rica are the result of climate change induced changes in litter dynamics. In addition to changes in the litter disturbance regime, I argue that changing litter dynamics as a result of peccary extirpation will also affect reptile and amphibian populations. Peccary loss could slow decomposition, resulting in more standing litter (i.e., more habitat) but also a reduction in microbial activity and thus a narrower base to the detrital food web (i.e., less food).

To determine the importance of large mammals in regulating ecosystem processes and leaf litter amphibian and reptile populations, I examined the hypothesis that a severe reduction (simulated extirpation) of collared peccary density would lead to changes in the amount and quality of leaf litter as habitat for the leaf litter reptiles and amphibians that live there. I compared the following characteristics in plots where peccaries were excluded to paired open plots that peccaries had access to: (1) macronutrient concentrations in soil and leaf litter, (2) relative cellulose decomposition rates, (3) 
understory vegetation density, (4) leaf litter depth, (5) humidity of leaf litter and soil, and (6) the abundance of leaf litter reptiles and amphibians. I expected to detect relatively slower leaf litter decomposition (as a result of reduced nutrient inputs near latrines, and reduced litter turnover elsewhere), and thus more standing litter in peccary exclusion plots. While increased standing litter means there might be more habitat in exclusion plots, there might also be less food available to litter organisms because microbial growth and arthropod populations would be limited by a reduction in nutrient availability. I expected peccary extirpation to affect litter reptile and amphibian populations depending on whether habitat or food is more limiting.

\section{METHODS}

\section{Study site}

I conducted my research at the La Selva Biological Station (hereafter La Selva), located in the Caribbean lowlands of northeastern Costa Rica in Heredia Province $\left(10^{\circ} 26^{\prime} \mathrm{N}, 84^{\circ} 00^{\prime} \mathrm{W}\right)$. La Selva is a 1600 ha private reserve owned by the Organization for Tropical Studies. The primary forest is described as lowland wet forest, located between $35 \mathrm{~m}-137 \mathrm{~m}$ asl, and receives $\sim 4 \mathrm{~m}$ of precipitation annually. For a complete description, see McDade and Hartshorn (1994).

\section{Peccary exclusion plots}

There are five mammal exclusion plots located in primary forest at La Selva. The plots are $20 \mathrm{~m} \times 50 \mathrm{~m}$ and are surrounded by a $\sim 2 \mathrm{~m}$ high chain-link fence which is expected to exclude large, non-arboreal and non-volant mammals (e.g., deer, tapirs, 
peccaries). Deer and tapir density at La Selva is very low (Timm 1994) so I expect that the plots are effective only for peccary exclusion. Small terrestrial mammals like agoutis and armadillos have access to all exclusion plots through burrows that extend under the fences. Each of the five exclusion plots has a paired control plot which is completely open to all mammals, and located on the same soil type and slope. The exclusion plots were established by Walter Carson in June 2000, and have existed in varying states of effectiveness because treefalls have occasionally broken fences and allowed access to the exclusion plots by peccaries. Since approximately March 2009, La Selva has actively maintained the exclusion fences to prevent access to peccaries. Data were collected from points based on random directions and distances using a grid system set up within the peccary exclusion and control plots (hereafter referred to by their La Selva trail acronyms: LOC2300, LOC2650, LS, SHO, SSO). In addition, no data were collected within a $1 \mathrm{~m}$ buffer from the fences inside the exclusion plots.

\section{Mammal activity}

\section{Seed removal}

I used Iriartea deltoidea seeds (mean weight \pm 1 SD: $4.4 \mathrm{~g} \pm 0.4 \mathrm{~g}$ ) which were collected approximately two months prior to use and held in plastic bags in an air conditioned room. I froze seeds for 24 hours before placing them in the plots to destroy viability. On 1 July 2011 I placed two 3 x 3 seed grids, with nine seeds each, on a cleared square of ground inside the five mammal exclusion plots. I placed paired control seed grids approximately $6 \mathrm{~m}$ away, outside the exclusion plots, following the same procedure. On 4 July 2011 I returned to each seed grid and recorded the number of 
missing seeds. I assumed that seed removal from the experiment was the result of seed predation by mammals. I removed all seeds from exclusion plots at the end of the study.

\section{Trampling}

I deployed artificial seedlings made of straws arranged in a T-shape with a paper clip "tap root" on transects inside and outside mammal exclusion plots. The artificial seedlings were monitored as indicators of trampling damage every two wk over an $8 \mathrm{wk}$ period from July-August 2010 (following Clark \& Clark 1989). I placed one $45 \mathrm{~m}$ transect, composed of 45 individual artificial seedlings spaced $1 \mathrm{~m}$ apart, inside the LOC2300, LS, and LOC2650 mammal exclusion and control plots.

\section{Camera traps}

I deployed motion-activated cameras on the LOC2300, LOC2650, SHO, and LS plots in March, July-August 2010, and June-July 2011. I attached the cameras to tree trunks at a height of approximately $50 \mathrm{~cm}$. I placed the camera traps inside peccary exclusion plots at suspicious-looking holes under the fences, and paired camera traps outside the fences at random locations along the border of control plots. The cameras were set to take three photographs after each trigger event. The number of independent animals captured by the cameras was compared between the exclusion and control plots.

\section{Litter dynamics}

\section{Litter fall}

Five $50 \times 50 \mathrm{~cm}$ mesh litter traps were placed at random locations within each 
plot and moved to a new random location every 2-3 months. Bi-weekly collections were combined as a monthly average from each trap, and control and exclusion plots were compared. All plant material except coarse woody debris (e.g., including flowers, fruits, and leaves, but not logs or sticks) was collected from the traps. Litter fall samples were dried in an oven at $60^{\circ} \mathrm{C}$ for at least 48 hours and then weighed.

\section{Canopy Density}

I estimated canopy cover over peccary exclusions and controls using a spherical densitometer. The densiometer was read in each cardinal direction at 20 random points on each plot in November 2009 and December 2010.

\section{Standing litter mass}

I estimated litter mass by collecting litter from inside $25 \times 25 \mathrm{~cm}$ quadrats $(\mathrm{n}=6$ in September, $\mathrm{n}=9$ in October-November, and $\mathrm{n}=15$ from December-March) from random locations within plots. I collected leaves, parts of leaves, and very small seed pods and fruits. As a general rule, large seed pods and fruits, and coarse woody debris were not collected. I transported the litter samples to the laboratory in a sealed plastic bag to retain moisture. I weighed the litter wet, dried it at $60^{\circ} \mathrm{C}$ for at least 48 hours, and weighed the dry litter. The loss in weight were assumed to be associated with loss of water and represents litter moisture .

\section{Standing litter depth}

Dial calipers $( \pm 0.1 \mathrm{~mm})$ were used to measure litter depth by piercing litter with 
the depth bar. The depth bar was extended and direct downward force was exerted until the soil was contacted. Some litter compression was expected by the action but I expected it to have no overall effect on relative depth as the same person took measurements in the same way on both exclusion and control plots. The number of leaves pierced by the depth bar was also recorded as another way to estimate litter depth.

\section{Cellulose decomposition}

I compared relative cellulose decomposition rates using a standard substrate decomposition experiment (Harmon et al. 1999). I compared the mass of cellulose lost in the mammal exclusion and mammal control plots, and in the presence or absence of peccary feces. Cellulose is a major component of the organic material in leaf litter (Berg and McClaugherty 2008). Five sheets of P8 coarse cellulose filter paper (Fisher Scientific, Pittsburg, PA, USA) were weighed in the laboratory and placed into plastic mesh bags $($ mesh size $=0.3 \mathrm{~cm})$. The mesh bags were expected to exclude macroinvertebrates larger than $0.3 \mathrm{~cm}$. I added $\sim 15 \mathrm{ml}$ of homogenized peccary fecal material $(\mathrm{P}+$ ) or $\sim 15 \mathrm{ml}$ of homogenized soil material (P0) from the corresponding plot to the mesh bags filled with cellulose paper. Bags were then sealed with three staples and placed on the forest floor on top of the leaf litter. One leaf was placed on top of each cellulose bag. I deployed the replicates in six blocks per plot in each of the five pairs of plots. One block consisted of three pairs of bags. Each pair had one $\mathrm{P}+$ and one P0 bag, and one pair from each block was collected after one, four, and eight weeks. After collection, I brought the mesh bags to the laboratory, cleaned the remaining cellulose paper of debris, dried it at $70^{\circ} \mathrm{C}$ for 24 hours, then reweighed on the same balance to 
determine the proportion of mass lost by decomposition. I conducted the decomposition experiment in October-November 2009 (wet season) and again in April-May 2010 (dry season). Monthly rainfall averages were determined from open-source La Selva meteorological station data (OTS, http://www.ots.ac.cr/meteoro/default.php?pestacion=2)

\section{Soil and litter nutrient concentrations}

I collected soil and leaf litter samples from 15 random points within each pair of plots $(\mathrm{n}=5)$ in January, February, and March 2010. I removed coarse roots from soil samples, dried the soil at $60^{\circ} \mathrm{C}$ for at least 48 hours, and then ground each sample to a coarse powder. I washed leaf litter samples with $1.5 \mathrm{~L}$ distilled water for 90 seconds to remove surface soil and arthropods, dried them at $60^{\circ} \mathrm{C}$ for at least 48 hours, and ground samples to a coarse powder. The 15 samples from each month were combined, ground to a fine powder, and a subsample was removed for analysis. Carbon and nitrogen contents were determined on an elemental analyzer (ThermoFisher Flash EA 1112). Phosphorus contents were determined using a dry oxidation/acid hydrolysis procedure (Fourqurean et al. 1992) followed by colorimetric determination of phosphate concentrations using the molybdenum blue technique and a spectrophotometer (Shimadzu UV2101PC).

\section{Understory vegetation density}

In November 2009 and February 2011, I estimated understory vegetation density using a modified Robel pole for visual obstruction measurements (Vermeire et al. 2002). I fixed alternating color bands (pink and black) to a $2.5 \mathrm{~cm}$ diameter $1 \mathrm{~m}$ long PVC tube. The tube was held horizontally at a randomly selected point $1 \mathrm{~m}$ above the ground. The 
observer stood $5 \mathrm{~m}$ away, lowered eye level to $1 \mathrm{~m}$ above ground, and then reported the number of visible pink bands. Understory stem density was compared by counting the number of stems within a $50 \times 50 \mathrm{~cm}$ quadrat placed at 10 random locations in each plot in November 2009.

\section{Reptile and amphibian relative abundance}

Modified Visual Encounter Surveys (VES; Crump \& Scott 1994) were conducted on $20 \times 20$ m mark-recapture plots inside each exclusion and control plot $(n=5)$. The leaf litter and understory (up to $2 \mathrm{~m}$ ) was searched thoroughly on each pair of plots for three consecutive days every month (October 2009 - May 2010) by 1-2 observers walking at a set pace in a standardized pattern for a minimum of 48 min. Plot sampling order, starting point, and direction of travel on each plot was randomized for each transect. I attempted to capture, identify, and weigh all amphibians and reptiles (except venomous snakes). I was unable to accurately measure weights when it was raining. Captures were marked with a unique toe-clip code for identification of recaptures (except snakes, and juvenile anurans $<10 \mathrm{~mm}$ Snout-Urostyle Length, SUL; Donnelly et al. 1994).

\section{Species identification}

Frogs, lizards, and snakes found on mark-recapture plots were identified in the field using characteristics and photos from Savage (2002) and Guyer \& Donnelly (2005). When animals could not be identified in the field, detailed characteristics notes, accompanied by photos if possible, were taken of the animal and later compared to 
species characteristics in Savage (2002). Animals including juveniles not identified to species were recorded to genus when possible.

\section{Statistical analyses}

Mammal activity

I conducted a $\chi^{2}$ test for independence in JMP (Version 5, SAS Institute) on the counts of damaged straws to determine if there was a relationship between plot location and peccary treatment. I examined the populations of all mammals and peccaries captured in photos using Wilcoxon Rank Sum tests using wilcox.test of the package stats in the statistical package R (R Development Core Team 2011).

\section{Litter dynamics}

I analyzed litter fall rates, the mass of standing litter, and standing litter depth data using linear mixed effects models with the lme procedure of package nlme in the statistical package R. To compare the amount of litter falling onto control and exclusion plots, I used dry litter fall mass (g) as the response variable, with peccary treatment and plot location as fixed factors and included sampling month as a random effect. I used the $\log$ (standing litter mass in $\mathrm{g}$ ) as the response variable, with peccary treatment as a fixed factor, and included sampling month and plot location as random factors. For litter depth, I used monthly averages of litter depth and the number of leaves as the response variables, with peccary treatment as a fixed effect and sampling month and plot location as random effects. I examined canopy density using a generalized linear mixed effects model with the lmer procedure of the lme 4 package in R, specifying peccary treatment as 
the fixed effect, plot location within sampling month as a random effect, and specifying binomial errors.

\section{Cellulose decomposition}

I examined the effects of peccary treatment and peccary fecal material addition on the proportion of mass lost from cellulose paper with linear mixed effects models with Ime in the statistical package R. I conducted the peccary treatment analysis with $\log$ (proportion of cellulose lost) as the response variable, experimental treatment as a fixed effect, and experiment duration (1, 4, or 8 weeks) within plot location (LOC2300, LOC2650, LS, SHO, or SSO) within season (Wet or Dry) as random factors. I conducted the fecal treatment analysis with $\log ($ proportion of cellulose lost) as the response variable, fecal treatment as a fixed effect $(\mathrm{P} 0=$ soil addition, $\mathrm{P}+=$ peccary feces addition $)$, and experiment duration within plot location as random effects.

I analyzed the differences in understory vegetation density between peccary treatments with generalized mixed effects models using lmer in the lme4 package of R, using peccary treatment as a fixed effect and plot location within sample month as random effects. I specified Poisson errors for stem density counts and binomial errors for the visual obstruction proportion data.

\section{Nutrients}

I analyzed the TP, $\mathrm{C}, \mathrm{N}$, and $\mathrm{C}: \mathrm{N}$ nutrient concentrations on plots with lmer, specifying peccary treatment as a fixed effect and plot location within sample month as a random effect. I specified binomial errors for all nutrient analyses. 


\section{Reptile and amphibian relative abundance}

I evaluated differences in the number of animals encountered on VES plots inside the peccary exclusion and control plots using a generalized linear mixed effects model with Poisson errors in lmer. I used number of encounters per sample month as a response variable, specified peccary treatment as the fixed factor, and I included plot location within sample month as random factors. I repeated the lmer analysis for all amphibians and reptiles, for all frogs, and for all reptiles (lizards and snakes) encountered on plots. I calculated the recapture probability for each plot by taking ((number of animals recaptured during each sample session) / (the number of marked animals known to be alive during each sample session))/100.

\section{RESULTS}

\section{Mammal activity}

Seed removal

In total, animals removed only two seeds from the experiment, each from separate grids in two different exclusion plots.

\section{Trampling}

Across all pairs of plots ( $\mathrm{n}=3), 37$ of the 270 straws were damaged during the 8wk experiment. Of the damaged straws, falling palm fronds or other plant debris damaged 29 (78\%), animal trampling contributed $5 \%$ of the damaged straws, $11 \%$ were damaged by unknown causes, and 5\% were completely absent from the transect. I found 
no relationship in the number of damaged straws between peccary treatments and among plot locations $\left(\chi^{2}=0.169, \mathrm{df}=2, \mathrm{P}=0.92\right)$.

\section{Camera traps}

I successfully deployed cameras for 97 trap days on control plots and 152 trap days on exclusion plots, and recorded 286 mammal encounters on control plots and 117 encounters on exclusions. The number of total mammal encounters on control and exclusion plots was not significantly different $(W=18, P=0.2571)$. The number of peccary encounters on control plots was significantly higher compared to exclusions ( $W=$ $23.5, P=0.01206)$. Peccaries accounted for only $1.7 \%$ of all mammal encounters on exclusion plots, compared to $27.0 \%$ of all mammal encounters on control plots. Mammals captured by photos included agoutis, armadillos, peccaries, pacas, opossums, skunks, rats, anteaters, ocelots, and humans.

\section{Litter dynamics}

Canopy density did not differ significantly between peccary treatments $(t=0.596, P=$ 0.551). Litter fall did not differ between experimental treatments $(t=-0.588611, P=$ 0.5564). I detected no significant differences in litter mass between experimental treatments $(t=0.153417, P>0.80$; Figure 2.1$)$. Peccary exclusion plots had approximately $20 \%$ deeper litter than controls, and that difference was significant $(t=$ 3.525233, $P=0.0012$; Figure 2.1). The number of leaves pierced was also greater on exclusion plots than control plots $(t=2.502, P=0.0124)$. Litter ground cover was not significantly different between experimental treatments $(t=0.794, P=0.427)$. There was 
no difference in leaf litter water content between peccary exclusions and controls $(t=-$ $0.007, P=0.995)$.

\section{Cellulose decomposition}

The addition of peccary fecal material resulted in a greater proportion of cellulose mass lost compared to soil addition $(t=-3.1608, P=0.0017)$. The proportion of cellulose mass lost was slightly greater in peccary exclusion plots than in control plots $(t=$ $2.257459, P=0.0246$ ), indicating that decomposition occurred more quickly in exclusions compared to controls (Figure 2.2).

\section{Nutrient analyses}

I did not detect an effect of peccary treatment on the concentrations of TP in leaf litter $(t$ $=0.024, P=0.980)$ or soil $(t=0.115, P=0.9082), \mathrm{C}$ in leaf litter $(t=-0.011, P=0.991)$ or soil $(t=-0.016, P=0.9873), \mathrm{N}$ in leaf litter $(t=0.002, P=0.9987)$ or soil $(t=-0.059$, $\mathrm{P}=0.953)$, or $\mathrm{C}: \mathrm{N}$ in leaf litter $(t=-0.007, P=0.9946)$ or soil $(t=0.0001, P=0.9997)$.

\section{Understory Vegetation Density}

Peccary exclusion did not affect understory vegetation density measured as stem density ( $t=0.381, P=0.703)$, or using the visual obstruction method $(t=1.079, P=0.28)$.

\section{Reptile and amphibian relative abundance}

All amphibian and reptile encounters on exclusion and control plots are summarized in Table 2. I recorded 1907 encounters of reptiles and amphibians from 27 species during 
the study. I encountered fewer reptiles and amphibians on exclusion plots compared to controls $(t=-3.408, P=0.000653$; Figure 2.3). I did not detect an effect of peccary exclusion on the number of encounters for frogs $(t=-0.189, P=0.85)$, or lizards $(t=-$ $1.178, P=0.239)$ when considered separately. Total biomass of amphibians and lizards was greater on exclusion plots than controls $(t=2.326009, P=0.0202$; Figure 2.4). I found no difference in recapture probability between peccary exclusions and controls $(t=$ $-0.233, P=0.816)$

\section{DISCUSSION}

In my study, I used peccary exclusion to simulate peccary extirpation, a condition found in tropical forests throughout Central and South America as a result of conflicts between humans and peccaries (Beck 2005). My study increases our understanding of the consequences of peccary loss on ecosystem level processes and leaf litter organisms. I detected trends that suggest that peccary exclusion has ecosystem-level effects on litter dynamics, cellulose decomposition, and the relative abundance and biomass of litter reptiles and amphibians. My results are particularly important because conflicts among wildlife and humans and the likelihood of local extirpations of medium-large mammals are increasing throughout the Neotropics.

The La Selva mammal exclusion fences allowed trespass onto the plots by peccaries and other terrestrial mammals because they were not well-maintained prior to March 2009. The trespass issue likely limits the effect size of peccary exclusion. My ability to detect ecosystem level effects of peccary extirpation was probably limited by the short effective exclusion time prior to beginning my Master's thesis field work. 
Camera trap monitoring indicated that, at least once during my study, on one plot (LOC2650), the exclusion fence was breeched by a peccary. Given the extensive monitoring of two other exclusion plots (LS and LOC2300) with camera traps, the continual monitoring of fence condition on all plots, rapid repairs when fence damage occurred, and lack of peccaries or their spoor encountered during hundreds of personhours inside the exclusion plots compared to frequent encounters with peccaries and spoor on control plots, I expect the fences have done a reasonable job at excluding peccaries and have reduced peccary density inside fenced plots compared to the forest. Photo-trapping on paired exclusion and control plots indicate that peccary abundance inside exclusion fences is near-zero compared to control plots, while there was no difference in median number of mammal encounters between exclusion and control plots. I expect that during the course of this study and a period of six to seven months before sampling began, the fences effectively excluded peccaries.

The La Selva mammal exclusion fences are riddled with armadillo burrows that allow access by other small mammals, unlike similar exclusion plots at Barro Colorado Island, Panamá, where the fences were buried to a depth of $25 \mathrm{~cm}$ to also exclude small terrestrial seed predators like agoutis (Royo \& Carson 2005). My camera trap data indicated that agoutis were common inside the La Selva mammal exclusions and were more likely to encounter seeds than peccaries, which is the reverse of the natural situation found throughout the La Selva forest. At La Selva, peccaries and agoutis are the most abundant terrestrial frugivores, and peccaries are most likely to encounter seeds first which indicates peccaries may be more abundant than agoutis or travel greater distances to forage (Kuprewicz 2010, Kuprewicz \& García-Robledo 2010). The conditions inside 
the exclusion plots thus represent an agouti-dominated seed predation landscape compared to a peccary-dominated seed predation landscape in the forest. Outside exclusion plots, agoutis are outcompeted by peccaries for seeds that have no defenses (like the common palms Iriartea deltoidea and Socratea exorrhiza; Kuprewicz \& GarcíaRobledo 2010), but inside the exclusions, I expect agoutis to be the major seed predators of these palms. In addition to dampening the effect size of peccary exclusion, seed predation by agoutis inside the exclusion plots should have caused plant species to differ from the rest of the forest because agoutis are unable to consume the chemically defended seeds of many plant species that peccaries, with their sacculated fore-guts for fermentation, are capable of exploiting (e.g., many legumes; Kuprewicz \& GarcíaRobledo 2010). Studies are currently underway to compare the current seedling and sapling structure of controls and peccary exclusions to when the plots were first established.

I detected trends that suggest that peccary exclusion does have ecosystem level effects on litter dynamics, even after a short treatment period. The amount of standing litter is very difficult to accurately measure because of great variation depending on the environmental conditions, hence the use of multiple metrics. The measured depth of litter and the number of leaves per point were both significantly greater in exclusion plots than in controls, while there was no detectable difference in litter dry mass. Over time, all three metrics seem to track rainfall relatively closely, although litter depth and number of leaves seemed to respond to rainfall more quickly than litter mass (Figure 2.1). These seasonal patterns are not surprising considering that leaf litter decomposition is most 
limited by temperature (which are almost always sufficiently warm for microbial decomposer growth in tropical lowland forests) and moisture.

If litter depth is indeed greater inside the exclusion plots than controls, there are implications for ecosystem function. The presence of deeper litter in exclusions implies that decomposition is too slow to keep up with litter fall compared to control plots. However, mass was lost much more quickly from cellulose paper on exclusion plots than on controls, suggesting that exclusion plots actually have faster rates of decomposition than controls. The apparent paradox is likely not a result of greater litter fall on exclusion plots, as there were no significant differences between mass of litter fall on exclusion and control plots. It is possible that the canopy and understory plant species dropping litter onto exclusions happen to have more slowly decomposing litter compared to controls. Absolute decomposition rates were not measured by my relative technique, and while cellulose is a major component of leaves and a standard substrate for decomposition experiments, cellulose is not the only component of leaf litter that determines decomposition rate. Litter decomposition rates are a function of the chemical (N, P, S, K, etc.) and structural (lignin:cellulose) composition of litter, the microhabitat conditions of temperature and humidity, and the microbial community available to colonize new leaves (Berg \& McClaugherty 2008). In addition, decomposition rates on one plot (LS) indicated that decomposition was actually faster on control plots rather than exclusions, highlighting that small differences in microhabitat characteristics are likely very important to decomposition dynamics. Instead of measuring relative microbial decomposition, I have reported relative decomposition by microbes and some small litter arthropods. The patterns in decomposition seen between exclusion and control plots 
should not be affected by the large mesh size, but should result in more total decomposition taking place by the end of the study (Milton \& Kaspari 2007).

If litter is deeper inside the exclusion plots than controls, there are also implications for the organisms that live in the leaf litter. Litter arthropod abundance is positively related to the amount of leaf litter (habitat), and arthropod diversity is related to forest floor nutrient concentrations (Sayer et al. 2010). In addition to providing habitat for leaf litter organisms such as arthropods, amphibians, lizards, and snakes, litter provides shelter from predators, a relatively stable thermal and humidity microclimate, and sites for reproduction. In addition, the decomposition of litter forms the bottom of the food web in which many litter arthropods, reptiles, and amphibians are top predators. Recent work by Shik \& Kaspari (2010) indicates that when litter decomposes quickly in response to an influx of nutrients, it provides food for the litter arthropods but destroys the habitat they depend on for shelter. If there is indeed more litter (i.e., more habitat) and faster decomposition (i.e., a broader base of the food web) on exclusions, I would expect there to be more biomass, specifically of arthropods and their vertebrate predators (i.e., frogs, lizards, and snakes) inside exclusions than on controls. I did detect significantly greater amphibian and reptile biomass on exclusion plots compared to controls.

However, of 1907 encounters of amphibians and reptiles during my study, I recorded $14.5 \%$ more encounters on control plots than on exclusions. For five out of the eight months that plots were sampled, there were more reptile and amphibian encounters on controls than exclusion plots. Exclusion fence permeability is unlikely to have been a confounding factor for all but the largest litter reptiles and amphibians, which were never 
(e.g., turtles) or only very rarely (e.g., large adult vipers) encountered on control plots. Encountered individuals include the number of first-time captures, repeat captures, and escaped animals and it might not reflect the actual relative abundance of amphibians and lizards on the plots because some animals are counted more than once. Measuring abundance of cryptically colored, motile organisms is also notoriously problematic as a result of differences in detection ability under different environmental conditions. I expect detection probability of leaf litter amphibians to be lower on exclusion plots than on control plots because of the deeper litter found there. Biased detection probability could be estimated using mark-recapture analyses, but my recapture rates for the common species were too low $(<15 \%)$ to estimate robustly the detection probability or other population parameters by the program MARK. Because I found no difference in the recapture probability of individual animals on control plots compared to exclusions, it is unlikely that the significant differences in encounters between treatments can be explained by differences in detectability alone.

Finding more amphibians and reptiles on control plots than exclusion plots could be explained at least in part by the intermediate disturbance hypothesis. Peccaries have intense foraging behaviors, especially relative to agoutis which are the other common terrestrial seed predators, because peccaries travel in larger groups and often dig into the soil and turn leaf litter over. Peccary foraging disturbances could provide a more heterogeneous array of available microhabitat conditions in control plots than exclusions. The biomass data suggest an alternative explanation. Differences in the ratio of juvenile animals to adults could explain why I encountered more individual animals on control plots yet found greater biomass on the exclusion plots. I would expect to see fewer 
juveniles on control plots because juveniles weigh less than adults but count as an encounter. If peccary disturbance has a negative effect on litter amphibian and reptile clutch success, I would also expect to see fewer juveniles on control plots compared to exclusions. I encountered 338 juveniles out of 558 encounters ( $39 \%$ juveniles) on control plots, compared to 242 juveniles out of 513 encounters ( $47 \%$ juveniles) on exclusion plots, indicating that peccaries might be negatively affecting clutch success on control plots.

Even on my five capture-recapture plots I was able to detect the seasonal patterns of amphibian and reptile abundance reported by Watling \& Donnelly (2002). Amphibian and reptile abundance and biomass track rainfall and leaf litter depth surprisingly well, which underscores the implicit linkages between amphibian and reptile populations, leaf litter as habitat, and the detrital food web. Leaf litter amphibian and reptile abundance has long been correlated with the availability of deep leaf litter and/or arthropod prey (Scott 1976, Inger 1980, Lieberman 1986, Heinen 1992, Watling \& Donnelly 2002, Whitfield \& Pierce 2005, Whitfield \& Donnelly 2006, Whitfield 2011). Litter amphibian and reptile populations are likely limited by some of the same environmental characteristics as the litter arthropods, either directly (as in the availability of deep litter for habitat) or indirectly, mediated through the availability of the arthropods themselves (along phosphorus gradients, for example), and these relationships could drive many of the patterns of patchiness among litter amphibian and reptile populations. Future studies should test directly the links among environmental characteristics, the arthropod fauna, and the leaf litter reptile and amphibian populations that appear to depend so strongly upon them. 
Amphibian and reptile abundance in Neotropical forests is also notoriously patchy, likely as a result of variation in characteristics of the leaf litter leading to differences in microhabitat quality and prey availability. Understanding the mechanisms driving patchiness might be especially important at La Selva because of a major ongoing decline in the leaf litter reptile and amphibian populations there (Whitfield et al. 2007). Whitfield et al. (2007) propose that forest-wide changes in leaf litter dynamics (e.g., decomposition rates and the amount of standing litter) have resulted in less standing litter available for litter animals, leading to declines. Although the mechanism proposed is climate change, I have shown that peccaries could also affect litter dynamics.

In my study I examined the effects of simulated collared peccary extirpation because white-lipped peccaries were extirpated from the region in the mid-1900s (Timm et al. 1989). Almost all of Central America is a case study in what happens to tropical forests after white-lipped peccary extirpation, a fact that should not be lost on researchers working in Central American forests. A data-vacuum regarding plant composition and forest structure before and after white-lipped peccary extirpation limits comparative research but would be extremely informative about the effects of current and future extirpations. White-lipped peccaries are larger than collared peccaries, travel around in large groups and have intensive foraging behaviors, with foraging herds essentially acting like bulldozers on the forest floor (Beck 2005). White-lipped peccaries have wide ranging movement patterns which likely affect any given spot in the forest much less frequently than collared peccaries (Carrillo et al. 2002, Keuroghlian et al. 2004, Beck 2005). Both Neotropical forest peccary species are likely to have strong local effects on plant nutrient availability, litter decomposition, and primary productivity near latrines and 
mineral licks. Future studies should examine the effect size of white-lipped peccary extirpation in tropical forests, particularly in Amazonia, and the ecosystem effects of peccary latrines.

My results indicate that even a short-term reduction in peccary densities can cause ecosystem-level effects on the detrital food web. A more effective exclusion treatment or actual peccary extirpation is likely to have a much greater effect on litter and litter organisms. The effects I detected on the declining litter reptiles and amphibians are especially important at La Selva. Whitfield (2011) and many other researchers at La Selva have suggested that a perceived increase in peccary abundance within the reserve might be to blame for changing litter dynamics and negatively affect everything from seed predation to understory bird abundance to reptile and amphibian populations. If peccaries were contributing to the leaf litter reptile and amphibian declines at La Selva, I would expect to have many more encounters inside the exclusion plots compared to the controls. The proportion of juveniles encountered may indeed be reduced in the presence of peccaries and should be investigated in greater detail, but I found no evidence that the presence of peccaries on control plots negatively affects litter amphibian and reptile populations. Researchers at La Selva should focus on other possible explanations for the ubiquitous decline of litter reptiles and amphibians, and focus on peccaries as vital components of the mammalian fauna rather than a problem to be dealt with.

\section{SUMMARY}

My results highlight the well-known fact that large-scale manipulations in complex environments like tropical forests rarely produce straightforward results, probably as a 
result of microhabitat variation in environmental factors like soil composition, throughfall nutrients, the timing and composition of litter fall, sun flecks, etc. I found that leaf litter was significantly deeper in peccary exclusion plots than in open controls, and that litter decomposition rates were typically higher in exclusion plots than in controls. I actually expected litter depth to be deeper in peccary exclusion plots as a result of slower decomposition, and this apparent paradox might be explained by treespecies differences in litter decomposability (lignin:cellulose ratios for example). I also found that litter amphibians and lizards were more commonly encountered on control plots than in peccary exclusions, which was surprising because compared to exclusions, control plots have relatively little habitat (leaf litter) and should have relatively little food (as a result of slower decomposition and nutrient limitation of arthropod populations). However, if the relatively higher number of amphibian and reptile encounters on control plots is not simply a result of differences in detection probability, these results suggest that the presence of peccaries in the La Selva forest does not have a negative effect on leaf litter organisms, contrary to anecdotal observations from long-term La Selva researchers. 


\section{LITERATURE CITED}

BARDGeTt, R. D. AND D. A. WARDLE. 2003. Herbivore-mediated linkages between aboveground and belowground communities. Ecology. 84: 2258-2268.

BECK H. 2005. Seed predation and dispersal by peccaries throughout the Neotropics and its consequences: a review and synthesis. In P. M. Forget, J. E. Lambert, P. E. Hulme, and S. B. Vander Wall (eds.). Seed Fate: Predation, Dispersal, and Seedling Establishment, pp. 77-115. University Press, Cambridge, UK.

BECK, H. 2006. A review of peccary-palm interactions and their ecological ramifications across the Neotropics. J Mammal. 87: 519-530.

BECK, H. 2007. Synergistic impacts of ungulates and falling palm fronds on saplings in the Amazon. J Trop Ecol. 23: 599-602.

Beck, H., A. Taber, M. Altrichter, A. Keuroghlian, and R. Reyna. 2008. Pecari tajacu. In IUCN 2011: IUCN Red List of Threatened Species. Version 2011.1. $<$ www.iucnredlist.org $>$. Downloaded on 03 August 2011.

BeCK, H., P. TheBPANYA AND M. FILIAGgi. 2010. Do Neotropical peccary species (Tayassuidae) function as ecosystem engineers for anurans? J Trop Ecol. 26: 407414.

Berg, B., AND C. MCClaugherTy. 2008. Plant litter: Decomposition, humus formation, Carbon sequestration, $2^{\text {nd }}$ Edition, 338 pages. Springer-Verlag, Berlin.

BODMER, R. E., J. F. EISENBERG AND K. H. REDFORD. 1997. Hunting and the likelihood of extinction of Amazonian mammals. Conserv Biol. 11: 460-466.

BODMER, R., AND D. WARD. 2006. Frugivory in large mammalian herbivore. In K. Danell, R. Bergstroem, P. Duncan, and J. Pastor (eds.). Large Herbivore Ecology Ecosystem Dynamics and Conservation, pp. 232-260. University Press, Cambridge, UK.

BRAdShaw, C. J. A., N. S. SodHI AND B. W. BROOK. 2009. Tropical turmoil: A biodiversity tragedy in progress. Frontiers in Ecology and the Environment. 7: 7987.

CARrillo, E., J. C. SAEnZ AND T. K. Fuller. 2002. Movements and activities of whitelipped peccaries in Corcovado National Park, Costa Rica. Biol Conserv. 108: 317324.

Clark, D. B. AND D. A. ClARK. 1989. The role of physical damage in the seedling mortality regime of a Neotropical rain-forest. Oikos. 55: 225-230. 
CRUMP, M.L, AND N.J. ScotT JR. 1994. Visual encounter surveys. In W.R. Heyer, M.A. Donnelly, R.W. McDiarmid, L.C. Hayek, and M.S. Foster, editors. Measuring and monitoring biological diversity: Standard methods for amphibians, pp. 84-92. Smithsonian Institution Press, Washington, DC.

DirZO, R. AND A. MirandA. 1990. Contemporary Neotropical defaunation and forest structure, function, and diversity - a sequel. Conserv Biol. 4: 444-447.

Donnelly, M. A., C. Guyer, E. J. Juterbock, And R. A. Alford. 1994. Techniques for marking amphibians. In W. R. Heyer, M. A. Donnelly, R. W. McDiarmid, and L. C. Hayek, editors. Measuring and monitoring biological diversity: standard methods for amphibians. Smithsonian Institution Press, Washington, D. C.

Duarte, H., M. Tejedo, M. Katzenberger, F. Marangoni, D. Baldo, J. F. Beltran, D. A. Marti, A. Richter-Boix, A. Gonzalez-Voyer. 2011. Can amphibians take the heat? Vulnerability to climate warming in subtropical and temperate larval amphibian communities. Global Change Biology (online early release; DOI: $10.1111 /$ j.1365-2486.2011.02518.x).

Estes, J. A., J. Terborgh, J. S. Brashares, M. E. Power, J. Berger, W. J. Bond, S. R. CARPenter, T. E. Essington, R. D. Holt, J. B. C. Jackson, R. J. MARQuis, L. Oksanen, T. Oksanen, R. T. Paine, E. K. Pikitch, W. J. Ripple, S. A. SAndin, M. Scheffer, T. W. Schoener, J. B. Shurin, A. R. E. Sinclair, M. E. Soule, R. VIRTANEN AND D. A. WARDLE. 2011. Trophic downgrading of planet Earth. Science. 333: 301-306.

FEELEY, K. 2005. The role of clumped defecation in the spatial distribution of soil nutrients and the availability of nutrients for plant uptake. J Trop Ecol. 21: 99102.

FeELEy, K. J. AND J. W. Terborgh. 2005. The effects of herbivore density on soil nutrients and tree growth in tropical forest fragments. Ecology. 86: 116-124.

FourquREAN, J.W., J.C. ZIEMAN, AND G.V.N. PowelL. 1992. Relationships between porewater nutrients and seagrasses in a subtropical carbonate environment. Mar Biol. 114: 57-65.

Fragoso, J. M. V. 1997. Tapir-generated seed shadows: Scale-dependent patchiness in the Amazon rain forest. J Ecol. 85: 519-529.

Fragoso, J. M. V., K. M. Silvius And J. A. CorreA. 2003. Long-distance seed dispersal by tapirs increases seed survival and aggregates tropical trees. Ecology. 84: 19982006. 
GILL, R. 2006. The influence of large herbivores on tree recruitment and forest dynamics. In K. Danell, R. Bergstroem, P. Duncan, and J. Pastor (eds.). Large Herbivore Ecology Ecosystem Dynamics and Conservation, pp. 170-202. University Press, Cambridge, UK.

Gongora, J., R. Reyna-Hurtado, H. Beck, A. TABer, M. Altrichter, And A. KeUROGHLIAN. 2011. Pecari tajacu. In: IUCN 2011. IUCN Red List of Threatened Species. Version 2011.2. <www.iucnredlist.org>. Downloaded on 15 November 2011.

Grelle, C. E. V. 2005. Predicting extinction of mammals in the Brazilian Amazon. Oryx. 39: 347-350.

Guariguata, M. R., J. J. R. AdAme And B. Finegan. 2000. Seed removal and fate in two selectively logged lowland forests with constrasting protection levels. Conserv Biol. 14: 1046-1054.

GuYer, C., AND M. A. Donnelly. 2005. Amphibians and Reptiles of La Selva, Costa Rica,and the Caribbean Slope. University of California Press, Berkeley.

HARMON, M.E., K.J. NADELHOFFER, AND J.M. BLAIR. 2009. Measuring decomposition, nutrient turnover, and stores in plant litter. IN G. Robertson, D. Coleman, C. Bledsoe, and P. Sollins (eds.). Standard Soil Methods for Long-Term Ecological Research, pp. 202-240. Oxford University Press, Oxford, UK.

Hector, A., J. Joshi, M. Scherer-Lorenzen, B. Schmid, E. M. Spehn, L. Wacker, M. Weilenmann, E. Bazeley-White, C. Beierkuhnlein, M. C. CAldeira, P. G. Dimitrakopoulos, J. A. Finn, K. Huss-Danell, A. Jumpronen, P. W. Leadley, M. Loreau, C. P. H. Mulder, C. Nesshoever, C. Palmborg, D. J. Read, A. S. D. SiamantZiouras, A. C. TERRY AND A. Y. TROUmBIS. 2007. Biodiversity and ecosystem functioning: Reconciling the results of experimental and observational studies. Funct Ecol. 21: 998-1002.

HEINEN, J. T. 1992. Comparisons of the leaf litter herpetofauna in abandoned cacao plantations and primary rain-forest in Costa Rica - some implications for faunal restoration. Biotropica. 24: 431-439.

Hester, A.J., M. Bergman, G. IAsON, AND J. Moen. 2006. Impacts of large herbivores on plant community structure and dynamics. In K. Danell, R. Bergstroem, P. Duncan, and J. Pastor (eds.). Large Herbivore Ecology Ecosystem Dynamics and Conservation, pp. 97-141. University Press, Cambridge, UK.

HobBie, S. E. AND P. M. VitouseK. 2000. Nutrient limitation of decomposition in Hawaiian forests. Ecology. 81: 1867-1877. 
Hooper, D. U., F. S. Chapin, J. J. Ewel, A. Hector, P. Inchausti, S. Lavorel, J. H. Lawton, D. M. Lodge, M. Loreau, S. Naeem, B. Schmid, H. Setala, A. J. SYMSTAD, J. VANDERMEER AND D. A. WARDLE. 2005. Effects of biodiversity on ecosystem functioning: A consensus of current knowledge. Ecol Monogr. 75: 335.

Huey, R. B., C. A. Deutsch, J. J. Tewksbury, L. J. Vitt, P. E. Hertz, H. J. A. Perez AND T. GARLAND JR. 2009. Why tropical forest lizards are vulnerable to climate warming. Proceedings of the Royal Society B-Biological Sciences. 276: 19391948.

INGER, R. F. 1980. Densities of floor-dwelling frogs and lizards in lowland forests of southeast-Asia and Central-America. Am Nat. 115: 761-770.

Isbell, F., V. Calcagno, A. Hector, J. Connolly, W. S. Harpole, P. B. Reich, M. SCHERER-Lorenzen, B. Schmid, D. Tilman, J. VAn RuiJven, A. Weigelt, B. J. WiLSEY, E. S. ZAVALETA AND M. LoREAU. 2011. High plant diversity is needed to maintain ecosystem services. Nature. 477: 199-U96.

SAS InSTITUTE INC. 1989-2006. JMP, Version 5. Cary, NC.

Kaspari, M., M. N. Garcia, K. E. Harms, M. SAntana, S. J. Wright And J. B. YavitT. 2008. Multiple nutrients limit litterfall and decomposition in a tropical forest. Ecol Lett. 11: 35-43.

Keuroghlian, A., D. P. Eaton And W. S. Longland. 2004. Area use by white-lipped and collared peccaries (Tayassu pecari and Tayassu tajacu) in a tropical forest fragment. Biol Conserv. 120: 411-425.

Keuroghlian, A. And D. P. EAton. 2009. Removal of palm fruits and ecosystem engineering in palm stands by white-lipped peccaries (Tayassu pecari) and other frugivores in an isolated Atlantic Forest fragment. Biodivers Conserv. 18: 17331750.

KuPREwicZ, E. K. 2010. The Effects of Large Terrestrial Mammals on Seed Fates, Hoarding, and Seedling Survival in a Costa Rican Rain Forest. UM Open Access Dissertations. Paper 391.

Kuprewicz, E. K. AND C. Garcia-Robledo. 2010. Mammal and insect predation of chemically and structurally defended Mucuna holtonii (Fabaceae) seeds in a Costa Rican rain forest. J Trop Ecol. 26: 263-269.

LiEBERMAN, S. S. 1986. Ecology of the leaf litter herpetofauna of a Neotropical rain forest: La Selva, Costa Rica. Acta Zoologica Mexicana (ns) 15:1-72. 
McDade, L. A., And G. S. HARTShORN. 1994. La Selva Biological Station. In L. A. McDade, K. S. Bawa, H. A. Hespenheide, and G. S. Hartshorn, editors. La Selva: Ecology and Natural History of a Neotropical Rain Forest, pp. 6-14. University of Chicago Press, Chicago.

MCGLYNn, T. P. 2006. Ants on the move: Resource limitation of a litter-nesting ant community in Costa Rica. Biotropica. 38: 419-427.

MCGlynn, T. P., R. M. FAwCETT AND D. A. Clark. 2009. Litter biomass and nutrient determinants of ant density, nest size, and growth in a Costa Rican tropical wet forest. Biotropica. 41: 234-240.

McGlynn, T. P., D. J. Salinas, R. R. Dunn, T. E. Wood, D. Lawrence And D. A. CLARK. 2007. Phosphorus limits tropical rain forest litter fauna. Biotropica. 39: 50-53.

Milton, Y. AND M. KASPARI. 2007. Bottom-up and top-down regulation of decomposition in a tropical forest. Oecologia. 153: 163-172.

PAINE, C. E. T. AND H. BECK. 2007. Seed predation by Neotropical rain forest mammals increases diversity in seedling recruitment. Ecology. 88: 3076-3087.

PERES, C. A. 2001. Synergistic effects of subsistence hunting and habitat fragmentation on Amazonian forest vertebrates. Conserv Biol. 15: 1490-1505.

Peres, C. A. AND E. Palacios. 2007. Basin-wide effects of game harvest on vertebrate population densities in Amazonian forests: Implications for animal-mediated seed dispersal. Biotropica. 39: 304-315.

R DEVELOPMENT CORE TEAM (2011). R: A language and environment for statistical computing. R Foundation for Statistical Computing, Vienna, Austria. ISBN 3900051-07-0, URL http://www.R-project.org/.

Reyna-Hurtado, R., A. Taber, M. Altrichter, J. Fragoso, A. Keuroghlian, and H. BECK. 2008. Catagonus wagneri. In: IUCN 2011. IUCN Red List of Threatened Species. Version 2011.1. <www.iucnredlist.org >. Downloaded on 16 September 2011.

RoldÁn, A. I. AND J. A. SimonetTI. 2001. Plant-mammal interactions in tropical Bolivian forests with different hunting pressures. Conserv Biol. 15: 617-623.

Royo, A. A. AND W. P. CARSON. 2005. The herb community of a tropical forest in central Panama: Dynamics and impact of mammalian herbivores. Oecologia. 145: 66-75. 
SAVAGE, J.M. 2002. The amphibians and reptiles of Costa Rica: A herpetofauna between two continents, between two seas, 934 pages. University of Chicago Press, Chicago.

SAYER, E.J., L.M.E. SutClifFE, R.I.C. Ross, E.V.J. TANNER. 2010. Arthropod abundance and diversity in a lowland tropical forest floor in Panama: the role of habitat space vs. nutrient concentrations. Biotropica. 42:194-200.

SCOTT, N. J. JR. 1976. The abundance and diversity of the herpetofaunas of tropical forest litter. Biotropica 8:41-58.

SHIK, J. Z. AND M. KASPARI. 2010. More food, less habitat: How necromass and leaf litter decomposition combine to regulate a litter ant community. Ecol Entomol. 35: 158-165.

Silman, M. R., J. W. Terborgh And R. A. Kiltie. 2003. Population regulation of a dominant-rain forest tree by a major seed-predator. Ecology. 84: 431-438.

Singer, F. J., W. T. SwANK, AND E. E. C. ClebSCH. 1984. Effects of wild pig rooting in a deciduous forest. J Wildl Manage. 48: 464-473.

SowLS, L. K. 1997. Javelinas and other peccaries: their biology, management, and use. Texas A\&M University Press, Texas, U.S.A.

Stoner, K. E., P. Riba-Hernandez, K. Vulinec And J. E. Lambert. 2007. The role of mammals in creating and modifying seedshadows in tropical forests and some possible consequences of their elimination. Biotropica. 39: 316-327.

TERBorgh, J. 1988. The big things that run the world - a sequel to Wilson,E.O. Conserv Biol. 2: 402-403.

Terborgh, J., L. Lopez, P. Nunez, M. Rao, G. Shahabuddin, G. Orihuela, M. Riveros, R. Ascanio, G. H. Adler, T. D. Lambert AND L. BAlbas. 2001. Ecological meltdown in predator-free forest fragments. Science. 294: 1923-1926.

Terborgh, J., G. Nunez-Iturri, N. C. A. Pitman, F. H. C. Valverde, P. Alvarez, V. SwAMY, E. G. Pringle AND C. E. T. PAINE. 2008. Tree recruitment in an empty forest. Ecology. 89: 1757-1768.

Thebault, E. And M. Loreau. 2006. The relationship between biodiversity and ecosystem functioning in food webs. Ecol Res. 21: 17-25.

Timm, R. M., D. E. Wilson, B. L. Clauson, R. K. LaVal, and C.S. Vaughan. 1989. Mammals of the La Selva-Braulio Carrillo complex, Costa Rica. North American Fauna 75: 1-162. 
Timm, R.M. 1994. The mammal fauna. In L.A. McDade, K. S. Bawa, H. A. Hespenheide, and G. S. Hartshorn, editors. La Selva: Ecology and Natural History of a Neotropical Rain Forest, pp. 229-237. University of Chicago Press, Chicago.

Vermeire, L. T., A. C. GANGULI AND R. L. Gillen. 2002. A robust model for estimating standing crop across vegetation types. J Range Manage. 55: 494-497.

VitouseK, P. M. 1984. Litterfall, nutrient cycling, and nutrient limitation in tropical forests. Ecology. 65: 285-298.

WARD, D. 2006. Long-term effects of herbivory on plant diversity and functional types in arid ecosystems. In K. Danell, R. Bergstroem, P. Duncan, and J. Pastor (eds.). Large Herbivore Ecology Ecosystem Dynamics and Conservation, pp. 142-169. University Press, Cambridge, UK.

WardLE, D. A. AND R. D. BARDGETT. 2004. Human-induced changes in large herbivorous mammal density: The consequences for decomposers. Frontiers in Ecology and the Environment. 2: 145-153.

Wardle, D. A., R. D. Bardgett, R. M. Callaway and W. H. Van der Putten. 2011. Terrestrial ecosystem responses to species gains and losses. Science. 332: 12731277.

WATLING, J. I. AND M. A. DonNELLY. 2002. Seasonal patterns of reproduction and abundance of leaf litter frogs in a Central American rainforest. J Zool. 258: 269276.

WhitfieLD, S. M. AND M. S. F. PIERCE. 2005. Tree buttress microhabitat use by a Neotropical leaf-litter herpetofauna. J Herpetol. 39: 192-198.

Whitfield, S. M. AND M. A. DonNelly. 2006. Ontogenetic and seasonal variation in the diets of a Costa Rican leaf-litter herpetofauna. J Trop Ecol. 22: 409-417.

Whitfield, S. M., K. E. Bell, T. PhilipPi, M. Sasa, F. Bolanos, G. Chaves, J. M. SAVAGE AND M. A. DonNelly. 2007. Amphibian and reptile declines over 35 years at La Selva, Costa Rica. Proc Natl Acad Sci U S A. 104: 8352-8356.

WHITFIELD, S.M. 2011. Litter dynamics regulate population densities of amphibians and reptiles in a declining tropical herpetofauna. In S.M. Whitfield. Enigmatic faunal declines at La Selva, Costa Rica: Patterns and processes in a collapsing Neotropical herpetofauna, pp. 153-182. FIU Electronic Theses and Dissertations. Paper 435. 
Wright, S. J. AND H. C. DuBER. 2001. Poachers and forest fragmentation alter seed dispersal, seed survival, and seedling recruitment in the palm Attalea butyraceae, with implications for tropical tree diversity. Biotropica. 33: 583-595.

Wright, S. J., H. Zeballos, I. Dominguez, M. M. Gallardo, M. C. Moreno and R. IBANEZ. 2000. Poachers alter mammal abundance, seed dispersal, and seed predation in a Neotropical forest. Conserv Biol. 14: 227-239.

Wright, S. J., A. HeRnAndeZ And R. CONDit. 2007a. The bushmeat harvest alters seedling banks by favoring lianas, large seeds, and seeds dispersed by bats, birds, and wind. Biotropica. 39: 363-371.

Wright, S. J., K. E. Stoner, N. Beckman, R. T. Corlett, R. Dirzo, H. C. MullerLandau, G. Nunez-Iturri, C. A. Peres And B. C. WANG. 2007b. The plight of large animals in tropical forests and the consequences for plant regeneration. Biotropica. 39: 289-291.

Table 2.1. Encounters of reptiles and amphibians in peccary treatments and controls.

\section{Peccary Treatment}

Control Exclusion

Total 
Frogs

Rhaebo haematiticus 2

Craugastor bransfordii

179

174

353

C. fitzingeri

7

C. megacephalus

48

1

C. mimus

12

53

C. noblei

6

22

C. talamancae

26

16

Pristimantis cerasinus

66

$P$. ridens

5

Diaspora diastema

7

Gastrophryne pictiventris

Lithobates warsczewitchii

1

2

241

Oophaga pumilio

Phylobates lugubris

Unidentified frog

31

27

41

102

11

6

16

1

4

471

1

Lizards

Ameiva festiva

Corytophanes cristatus

Norops biporcatus

1

N. capito

$N$. carpenteri

8

1

201

$N$. humilis

1

87

N. limifrons

Sphenomorphus cherriei

10

18

51

58

3

1

14

4

379

1

162

Unidentified lizard

Snakes

Bothrops asper

3

7

10

Bothriechis schlegelii

3

Imantodes cenchoa

1

Porthidium nasutum

2

4

2

Unidentified snake

Unidentified

Total

1

1028

2

3

FIGURES 


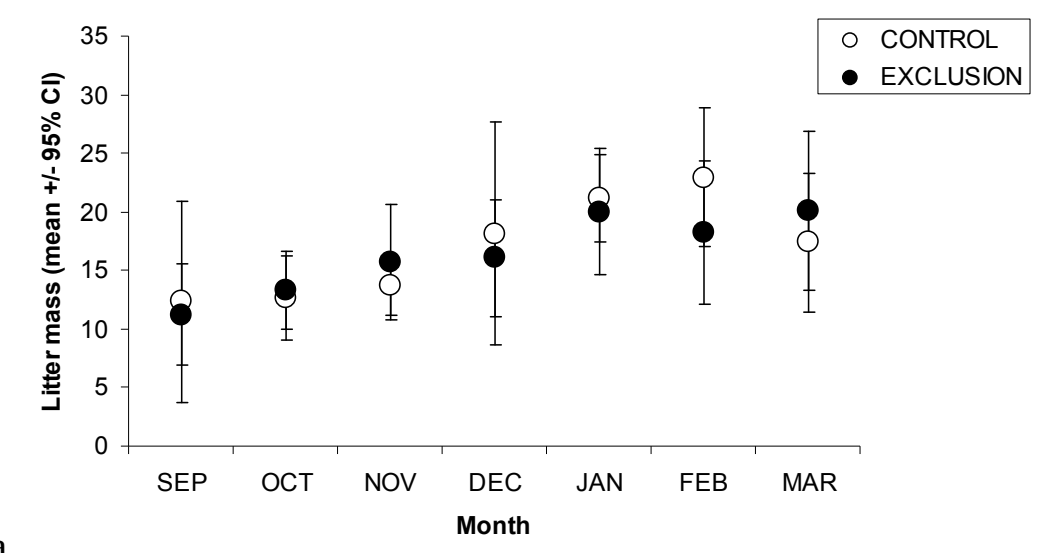

a.

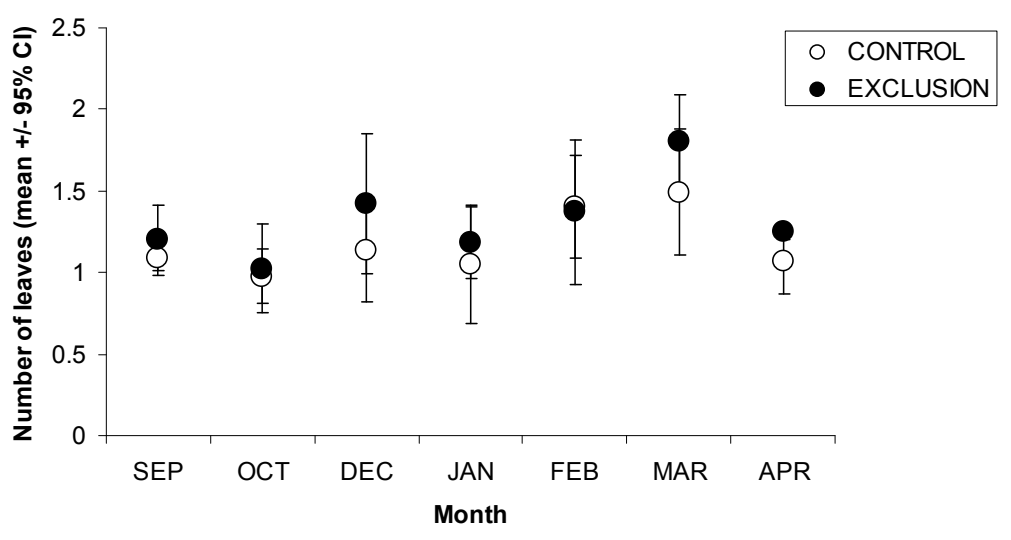

b.

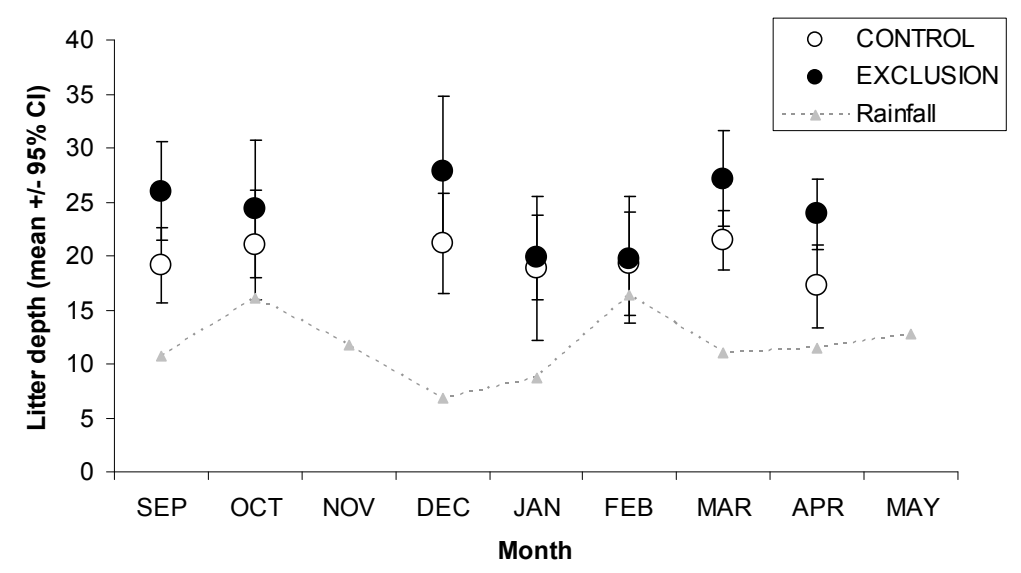

Figure 2.1. Effects of peccary treatment on metrics of litter depth. 


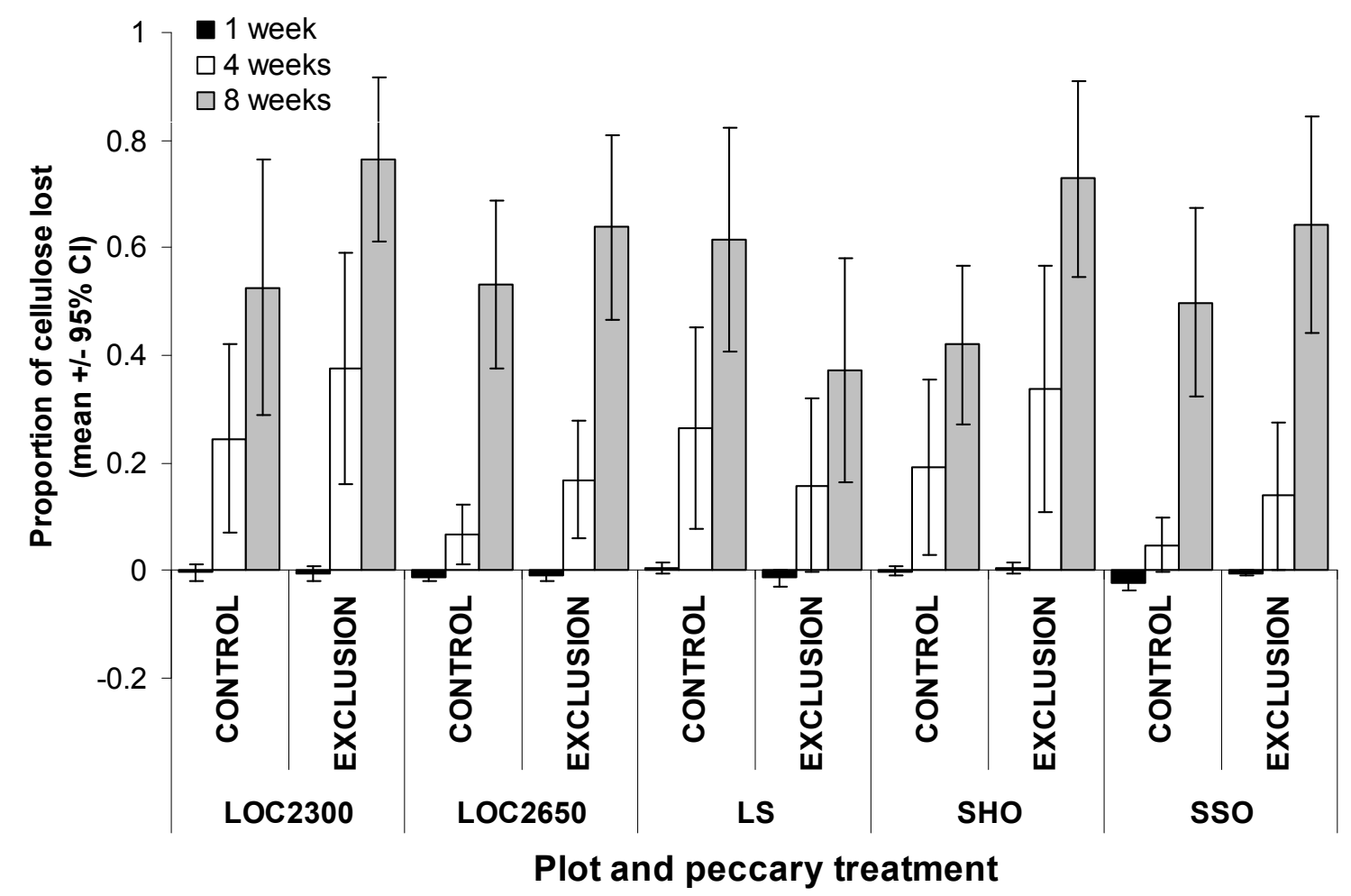

Figure 2.2. Effects of peccary treatment on the proportion of cellulose mass lost, a metric of decomposition, after 1 week, 4 weeks, and 8 weeks of exposure. 


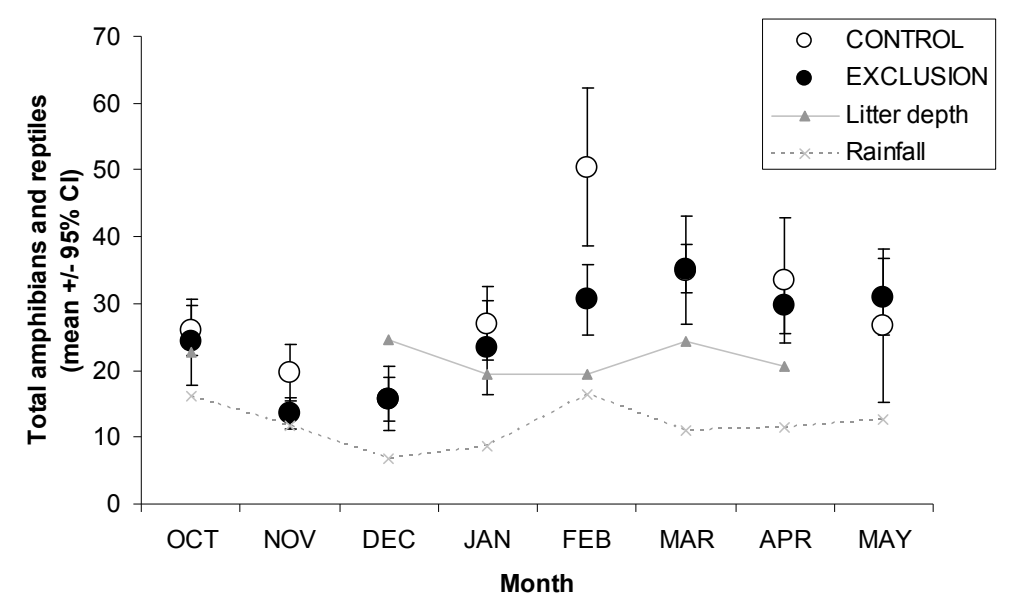

a.

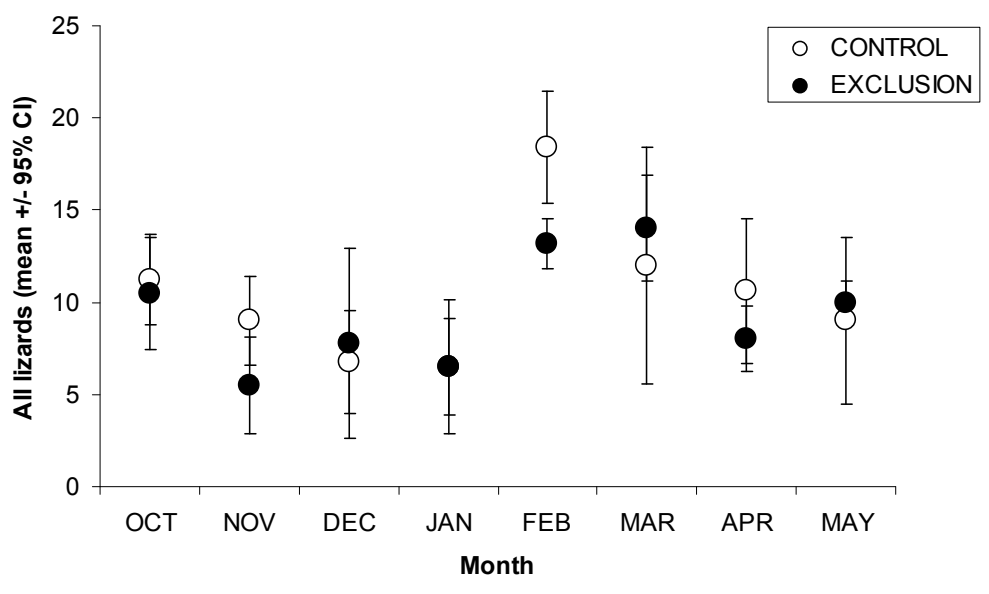

b.

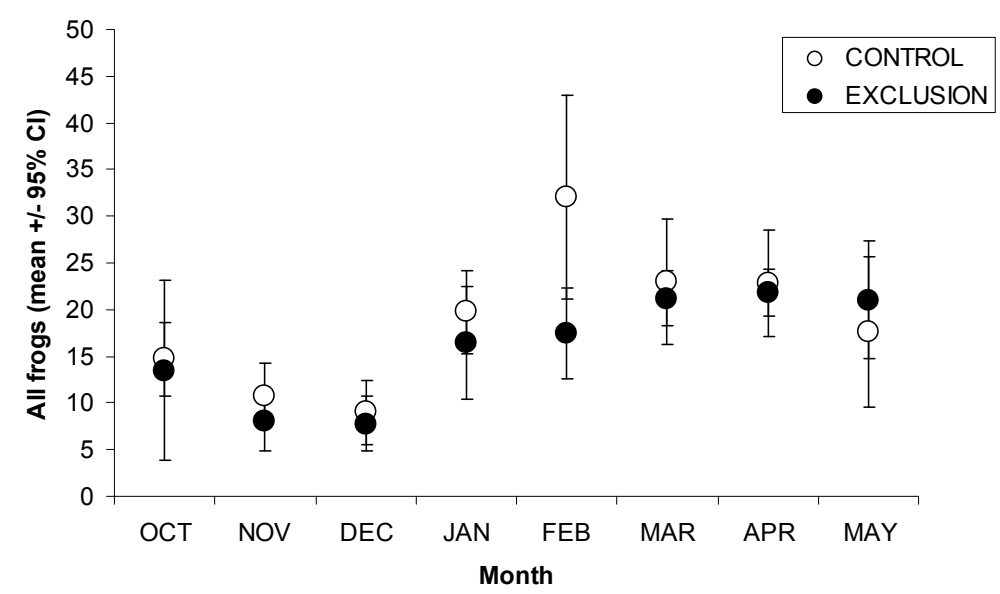

Figure 2.3. Monthly average of encounters on peccary exclusions and controls for a) total amphibians and reptiles, b) reptile encounters alone, and c) frog encounters alone. 


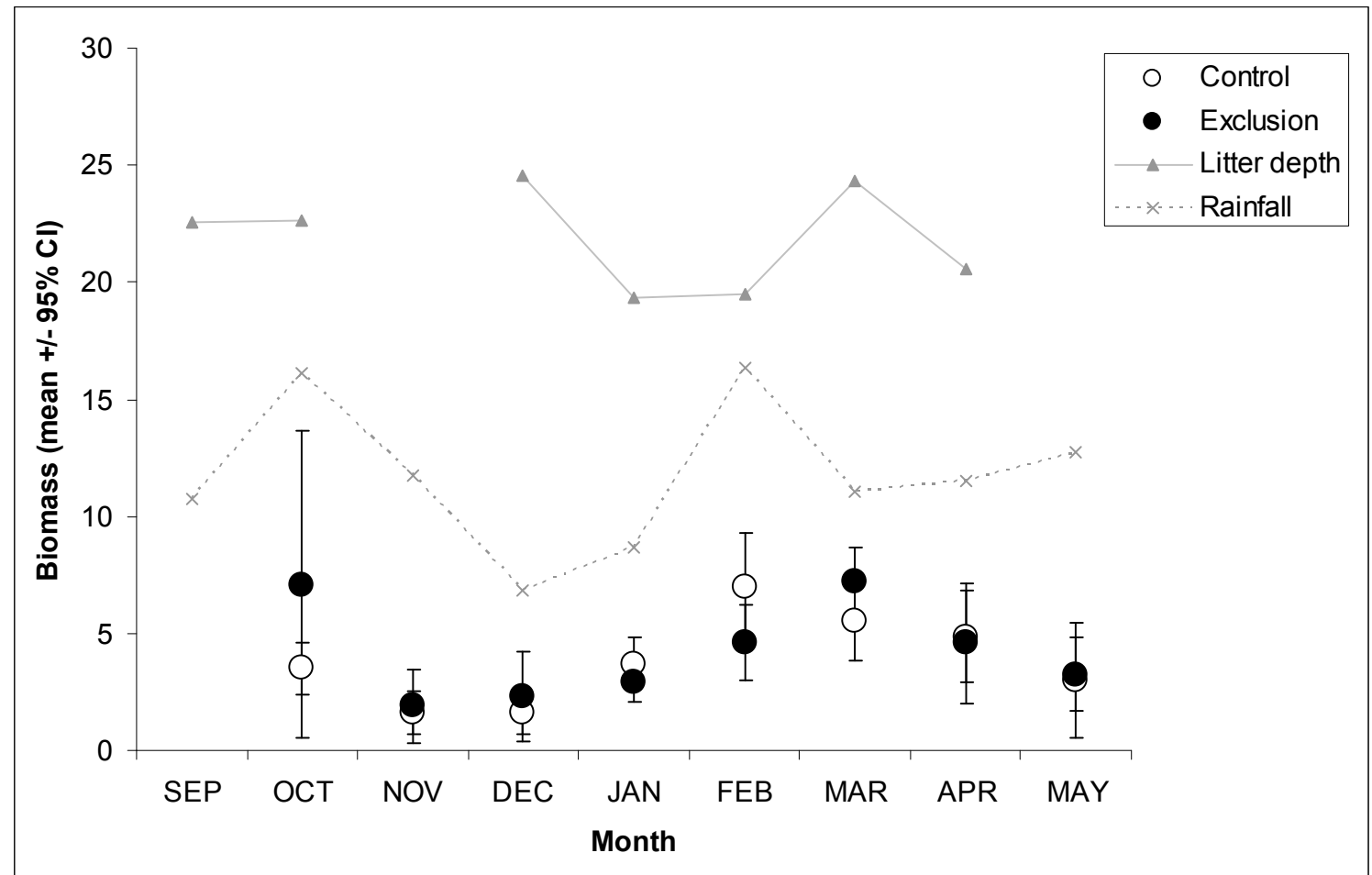

Figure 2.4. Biomass of all amphibians and reptiles captured and measured, with rainfall and litter depth trends. 


\section{CONCLUSIONS}

The peccary exclusion plots studied here contained 20\% deeper litter and had cellulose decomposition rates that were $23 \%$ faster on average than control plots.

Although I predicted that exclusion plots would thus provide more habitat and prey for amphibians and reptiles, I encountered approximately $15 \%$ fewer amphibians and reptiles on exclusions. The relationships among rainfall, standing litter depth, and the abundance and biomass of amphibians and reptiles seem to be stronger than the differences in abundance between peccary treatments. My study underscores the important linkages between the detrital food web and populations of the leaf litter amphibians and reptiles. I suggest that future research investigate the role of litter amphibians and reptiles as vital components of the detrital food web. In addition, my data suggest that peccaries are not contributing to the major ongoing decline of litter amphibians and reptiles at La Selva.

These findings are important because so much of our current understanding of tropical forest ecosystems is derived from research completed at La Selva. If peccaries are causing unusual conditions in the detrital food web and contributing to major declines in leaf litter amphibians and reptiles, then much of the research conducted at La Selva would be difficult to apply to other sites. If excessive trampling and litter turnover are negatively affecting litter organisms at La Selva, it is likely more of an issue very near the laboratory clearing where trampling and disturbance by both peccaries and humans are concentrated.

Given the information presented in Chapter One, peccaries do have great potential for influencing ecosystem process and the detrital food web. For example, the areas 
around peccary latrines are probably very affected by nutrient inputs and it might be expected that plants respond to these concentrated nutrient resources. Part of the mystery surrounding peccaries at La Selva is that very few data exist to determine whether the population is increasing. The frequency of disturbance by peccaries on the forest floor is likely very important for determining whether they have positive, neutral, or negative net effects on ecosystem function and biodiversity. Thus, estimating and monitoring the peccary population at La Selva and tracking herd movements would contribute greatly to efforts of understanding their ecological roles in the reserve. As long as the peccary exclusion fences continue to be well-maintained, the effect size of peccary exclusion on many ecosystem properties should increase with time. 